ARCHIWA, BIBLIOTEKI

I MUZEA KOŚCIELNE 111 (2019)

https://doi.org.10.31743/abmk.2019.111.18

JOLANTA WASILEWSKA* - LUBLIN

\title{
WACHLARZ W KOŚCIELE WSCHODNIM I ZACHODNIM ORAZ W KULTURZE ŚWIATA
}

\section{Streszczenie}

Historia wachlarza, wydawałoby się przedmiotu zbytkownego (a nawet zbędnego), jest niezwykle bogata i ciekawa z punktu widzenia obyczajów, historii i historii sztuki. To zdumiewające, jak ta niewielka rzecz codziennego użytku, współcześnie zaliczana do utensyliów mody kobiecej, przez tysiąclecia pełniła wielorakie i ważne funkcje.

Od najdawniejszych czasów wachlarze były używane do ochłody, odpędzania owadów, ochrony przed słońcem czy do rozniecania ognia. W starożytnym Egipcie wachlarze paradne używane były przez faraonów i kapłanów jako atrybuty władzy i dostojeństwa. Do lat 50. XX wieku w Kościele Zachodnim były używane dwa wachlarze (flabella) jako wyróżnienie honorowe w procesjach, podczas których niesiono papieża na sedia gestatoria. W liturgii Kościoła Wschodniego do naszych czasów przetrwało używanie wachlarzy (ripidia), chociaż ich znaczenie stało się już zupełnie symboliczne.

Znane są także wachlarze bojowe. Wywodzą się z Dalekiego Wschodu, gdzie służyły przede wszystkim jako oznaka rangi oficerskiej, ale także jako broń. Używane były od VI do XVI wieku, kiedy to osiągnęły szczyt popularności.

Wachlarze do Europy przybyły wraz z wyprawami na Daleki Wschód. W XVII i XVIII wieku nastały złote czasy wachlarzy. Królowały w salonach wyższych sfer i na dworach królewskich całej Europy. Były symbolem dostatku, wykwintności i kokieterii bez względu na porę roku. Wachlarz stał się atrybutem damy. Największą popularność zyskały wachlarze składane.

Wachlarze wykonywane były $\mathrm{z}$ drewna, metali szlachetnych, kości słoniowej, szylkretu, skóry, pergaminu, jedwabiu, płótna, papieru, piór, także z liści; były rzeźbione, malowane, haftowane i ozdabiane klejnotami.

* Jolanta Wasilewska - mgr historii sztuki; starszy kustosz dyplomowany w Bibliotece Uniwersyteckiej KatolickiegoUniwersytetu Lubelskiego Jana Pawła II; e-mail: jolanta.wasilewska@kul.pl https://orcid.org/0000-0003-0892-2766 
Przybierały różne formy w zależności od zastosowania i potrzeb, były małe i duże, proste, składane, plisowane, okrągłe, półkoliste, w kształcie liścia, chorągiewki, na długim lub krótkim uchwycie.

Słowa kluczowe: wachlarz typu ekran; oganiaczka; składany; brisé; Ripidion; flabellum; wachlarz na Bliskim i Dalekim Wschodzie; wachlarze japońskie osobiste; teatralne; wojenne; wachlarz chiński; koreański

\section{Wstęp}

Historia wachlarza - na pierwszy rzut oka zwykłego przedmiotu zaliczanego do akcesoriów damskiej mody - obfituje w niezwykle ciekawe aspekty z punktu widzenia historii, historii sztuki czy historii obyczajów. Wachlarz spełniał wielorakie funkcje w ciągu swojej historii, liczącej tysiące lat.

Pierwotna forma wachlarza wywodzi się wprost z natury, gdyż naturalnym pierwszym wachlarzem był po prostu duży liść (czy ich pęk), którym, mniej lub więcej skutecznie, człowiek odganiał się od owadów lub się chłodził. Służył on także do usuwania ze zboża pyłu i plew. W starożytności niewolnicy wachlowali swoich panów, gdy doskwierały im upały. Obok tych podstawowych, praktycznych i służebnych funkcji powstawały wachlarze mające inne zastosowanie, np. ceremonialne czy liturgiczne.

\section{Epoka chrześcijańska}

Ludność zamieszkująca kraje nad Morzem Śródziemnym, z uwagi na warunki klimatyczne, stosowała różne formy wachlarzy, naśladując wzornictwo od starożytnych krajów północnej Afryki. Do nowych sytuacji wyznaniowych wachlarz znalazł zmienioną symbolikę, np. w pismach św. Hieronima spotyka się opinię, że jest on oznaką wstrzemięźliwości ${ }^{1}$. W okresie przedromańskim ${ }^{2}$ wynaleziono nowe formy wachlarza: kolistą i tarczową, które stają się dominujące przez całe chrześcijańskie średniowiecze. Wachlarzy używano w liturgii Mszy Świętej - ripidion ${ }^{3}$ w Kościele obrządku wschodniego i flabellum ${ }^{4}$ obrządku zachodniego oraz służyły do odpędzania od ołtarza owadów, a także do podsycania ognia i dymu kadzideł. Wachlarze miały proste konstrukcje i służyły mniej więcej do XV wieku. Zastosowanie jakie wachlarz znalazł w Kościele było

${ }^{1}$ Świętym Hieronimowi i Flugencjuszowi przypisuje się zawód rzemieślników wytwarzających wachlarze. M. Selwa, Porozmawiajmy: o wachlarzach, cz. 1, https://kolekcjonersurowcow. wordpress.com/2011/11/16/porozmawiajmy-o-wachlarzach-cz-1/ (dostęp: 09.05.2019).

${ }^{2}$ Okres przedromański, termin przyjęty na określenie wczesnego średniowiecza od $\mathrm{V}$ wieku do pierwszej połowy XI wieku. Słownik terminologiczny sztuk pięknych, red. K. Kubalska-Sulkiewicz, Warszawa 2019, s. 334.

${ }^{3}$ Ripidion (gr.) hagion ripidion, „święty wachlarz” - płaski metalowy dysk przedstawiający głowę anioła Serafina otoczoną sześcioma skrzydłami ustawionymi pionowo. Przedmiot liturgiczny należący do kultu wschodniego. Zwykle wykonany z metali szlachetnych, jest wyposażony w rączkę. Ripidion,. https://fr.wikipedia.org/wiki/Ripidion (dostęp: 10.05.2019).

${ }^{4}$ Flabellum (łac.) - dużych rozmiarów wachlarze, najczęściej wykonane z pawich i strusich piór, umocowane na długiej rączce, używano ich jeszcze w ceremoniach w XX stuleciu. J. Stefański, Flabellum, w: Encyklopedia katolicka, t. 5, red. F. Gryglewicz, Lublin 1989, kol. 312-13. 
dość ważne; chodziło o to, by podczas sprawowania eucharystii nie doszło do zanieczyszczenia ciała i krwi Chrystusa. Liturgiczne użycie wachlarzy zaczyna się bardzo wcześnie w historii chrześcijańskiej, dlatego można zauważyć duże podobieństwa $\mathrm{w}$ ich stosowaniu na Wschodzie, jak i na Zachodzie. Ich użycie notuje się co najmniej od IV wieku, o czym świadczy chociażby fragment VIII księgi Konstytucji apostolskich: „Niech dwaj diakoni stojąc po obu stronach ołtarza i wachlarzem z delikatnej błony lub płótna albo pawim piórem niechaj łagodnie odganiają fruwające owady, by nie wpadły do kielichów"s.

\section{W Kościele obrządku wschodniego}

We wschodnich kościołach chrześcijańskich (w tym we wschodnich kościołach katolickich, wschodnich kościołach prawosławnych i orientalnych kościołach prawosławnych) od IV wieku używane są podczas nabożeństw uroczyste wachlarze zwane ripidionami lub hexapterygami ${ }^{6}$. Wachlarz ma formę osadzonego na długim trzonku krążka, rzadziej czworokąta, najczęściej ze złota lub srebra, ozdobionego po obu stronach wizerunkami sześcioskrzydłych serafinów. Ripidiony niesione są przez diakonów podczas liturgii celebrowanej przez biskupa, przy wszystkich procesjach z darami eucharystycznymi i księgami Ewangelii ${ }^{7}$. W rosyjskich kościołach są one często używane do uczczenia szczególnie świętej ikony lub relikwii. W Bizantyjskich Wschodnich Kościołach Katolickich ${ }^{8}$ i tradycji greckiej ${ }^{9}$ wachlarze, kiedy nie są używane, są umieszczane zazwyczaj na podwyższeniach za ołtarzem. Ripidiony używane $\mathrm{w}$ tradycjach maronickich i orientalnych (np. koptyjskie, ormiańskie, etiopskie) mają charakterystyczne małe obręcze z metalu lub dzwonki na całym obwodzie krążka, symbolizujące hymny aniołów dla Boga. W szczególnie uroczystych częściach liturgii są delikatnie potrząsane, aby wytworzyć brzęczący dźwięk, podobny do dźwięku dzwonków ołtarzowych ${ }^{10}$. W prawosławnym i grekokatolickim Kościele do dnia dzisiejszego wachlarze używane są w czasie mszy, procesjach i święceniach biskupów, a diakon $\mathrm{w}$ święceniach otrzymuje ripidion hagion (poświęcony wachlarz) ${ }^{11}$.

${ }^{5}$ Konstytucje apostolskie, VIII, 12,3, w: Synody i kolekcje praw, t. 2, Kraków 2007, s. 235 *.

${ }^{6}$ Miały odpędzać muchy i inne owady od elementów eucharystycznych.

${ }^{7}$ Diakoni przynoszą dary na ołtarz; kapłani asystują po obu stronach biskupa; dwaj diakoni z obydwu stron ołtarza odpędzają wachlarzami muchy od kielicha. Wachlarz liturgiczny we wschodnim chrześcijaństwie, https://en.wikipedia.org/wiki/Liturgical_fan_in_Eastern_Christianity (dostęp: 15.05.2019).

${ }^{8} \mathrm{~W}$ liturgii bizantyjskiej wachlarz symbolizuje obecność sił niebiańskich przy sprawowaniu liturgii. Tamże.

${ }^{9}$ Jednak w kościele greckim wachlarze nie są znane jako ripidia, ale jako hexapteryga, co oznacza sześcioskrzydłe serafiny. Tamże.

${ }^{10}$ P. Palazzini, Flabelli, w: Enciclopedia Cattolica, Vaticano 1950, kol. 1438-39.

${ }^{11}$ Stefański, Flabellum, kol. 312-13. 


\section{W obrządku Kościoła zachodniego}

W liturgii łacińskiej wachlarz zwany flabellum ${ }^{12}$ był używany w czasie mszy do odpędzania owadów od kielicha z hostią, a noszony obok papieża dodawał mu godności w ceremoniach kościelnych, czasami też był częścią dekoracji ołtarza. Flabellum lub muscarium (wachlarz do odpędzania much) miały niewielkie rozmiary, a wykonane były z pór, cienkiej skóry, pergaminu lub płótna. W liturgii łacińskiej wachlarze używane były w czasie mszy od IX wieku, a w XIV wieku wycofano się z ich używania ${ }^{13}$.

W Kościele Zachodnim pozostały w użyciu tylko wachlarze ceremonialne występowały one zawsze w parze. Używane były jako element ozdobny w procesjach podczas wielkich świąt kościelnych (m.in. Zwiastowanie Pańskie, Wielki Czwartek, Rezurekcja, Wniebowstąpienie, Boże Ciało, Wniebowzięcie, Koronacja i Konsekracja nowego papieża, Boże Narodzenie) ${ }^{14}$. W procesjach z udziałem papieża, kiedy niesiony był na sedia gestatoria ${ }^{15}$, wachlarze jako symbol jego władzy noszone były przez kamerdynerów zwanych anteambulones seu pedisequi famuli ${ }^{16}$.

Były to wielkie wachlarze wykonane $\mathrm{z}$ białych piór strusich oraz pawich ${ }^{17}$, zebranych w dwóch rzędach na półokrągłym lub trójkątnych stelażu z motywem kluczy piotrowych, umocowanych na długim drążku pokrytym szkarłatnym aksamitem, obszytym złotą nicią na całej długości ${ }^{18}$.

\section{Starożytność}

Egipt. Najstarsze przedstawienia wachlarzy pochodzą sprzed czterech tysięcy lat ${ }^{19}$. W Egipcie wytwarzano je, wzorując się na wachlarzach ludów kontynentu afrykańskiego. Egipcjanki używały dużych wachlarzy z liści lub piór, osadzonych na długich uchwytach (1,5 - 2 m długości). Technologia ich wytwarzania w Egipcie była na bardzo wysokim poziomie, przede wszystkim poziom artystyczny był mistrzowski. Na przestrzeni całej historii starożytnego Egiptu odnajduje się różne style i mody, odnoszące się także do wachlarzy ${ }^{20}$.

${ }^{12}$ Flabellum $\mathrm{z}$ łac. jest zdrobnieniem od flabrum - dmuchanie, podmuchy wiatru.

${ }^{13}$ Papież Paweł VI (1963-1978) zniósł używanie flabellum, nadal stosowane są w liturgii armeńskiej i greckiej. Wachlarz, w: Leksykon liturgii, oprac. B. Nadolski, Poznań 2006, s. 1670.

${ }^{14}$ Dizionario di erudizione storico-ecclesiastica, comp. G. Moroni, Venezia 1844, vol. 25, s. $37-38$.

${ }^{15}$ Rodzaj tronu, papieska lektyka, noszona na ramionach przez tak zwanych sediari. Używana była do 1978. Ostatnim jej użytkownikiem był papież Jan Paweł I. Jego następca Jan Paweł II odstąpił od zwyczaju noszenia papieża w lektyce. Ostatecznie sedia gestatoria została zastąpiona przez papamobile. J. Orlandis, Kościót katolicki w drugiej połowie XX wieku, Radom 2007, s. 123.

${ }^{16}$ Stefański, Flabellum, kol. 312.

${ }^{17}$ Oczka na pawich piórach symbolizowały oczy ludu, który śledził papieża w jego posłudze.

${ }^{18}$ Dizionario di erudizione storico-ecclesiastica, s. 87.

${ }^{19}$ Wachlarz był noszony przed władcami, szczególnie na Wschodzie (Egipt, Asyria, Babilonia). Leksykon liturgii, s. 1670.

${ }^{20}$ Obrazy wachlarzy znajdują się na malowidłach, reliefach w grobowcach faraonów i wysokich dostojników. 
We wszystkich okresach najpowszechniejszymi typami wachlarzy były pęki dużych liści lotosu, palmy daktylowej lub piór umocowanych na długich trzonkach ze złota albo kości słoniowej, niekiedy zgiętych pod kątem prostym u nasady. Rzadziej spotykane typy były wzorowane na liściach innych roślin albo skrzydeł dużych ptaków. W gorącym, dusznym klimacie Egiptu wachlarz był niezbędnym elementem wyposażenia, przeznaczonym do zapewnienia cienia i chłodu ${ }^{21}$. Postrzegany był także jako święty instrument używany w ceremoniach religijnych i dworskich, a także jako symbol (atrybut) władzy królewskiej22. Noszenie wachlarza $\mathrm{w}$ procesjach za dostojnikiem świadczyło o jego uznanej pozycji w hierarchii państwowej - był to najczęściej urzędnik wysokiej rangi lub zasłużony w walce żołnierz ${ }^{23}$. Wachlarz musiał więc być też uważany za przedmiot ważny i reprezentacyjny, towarzyszył bowiem zmarłym $\mathrm{w}$ ich pośmiertnych wędrówkach ${ }^{24}$. W grobowcu faraona Tutanchamona znaleziono osiem wachlarzy na długich trzonkach. Jeden z nich leżał tuż przy ręce faraona; miał nieco ponad metr długości. Półokrągły stelaż, w którym pierwotnie znajdowały się pióra, pokryto grubą złotą folią. Jego obie strony mają wytłoczone sceny z polowania faraona. $\mathrm{Z}$ jednej strony widać scenę polujących na strusie ${ }^{25}$, $\mathrm{z}$ drugiej triumfalny powrót faraona trzymającego pod pachą pióra, a jego towarzysze niosą zabite ptaki. Same pióra (42, na przemian białe i brązowe) nie przetrwały próby czasu. Pionowy napis $\mathrm{w}$ dole rękojeści informuje o szczegółach polowania, które miało miejsce na pustyni w pobliżu Heliopolis ${ }^{26}$. Jednak najbardziej niezwykłym wachlarzem

${ }^{21}$ Z. Żygulski jun., Kostiumologia, Kraków 1972, s. 14.

${ }^{22}$ Do oznak godności królewskiej należał wachlarz z włosia do odpędzania much. M. Gutowska, Historja ubiorów, Lwów 1932, s. 15.

${ }^{23} \mathrm{~W}$ Egipcie jedynie sam faraon miał prawo go używać; urzędnik noszący wachlarz z lewej strony tronu zaliczał się do rzędu wysokich dygnitarzy. A. Nowowiejski, Wykład liturgji Kościoła Katolickiego, t. 2, cz. 1, Warszawa 1902, s. 466.

${ }^{24}$ Dwa stelaże wachlarzy znalezione w grobowcu Tutanchamona pochodzą z 1349 roku p.n.e., wykonane misternie ze złota, świadczą o wysokim poziomie artystycznym, jaki osiągnęli Egipcjanie. Wachlarze znajdują się w muzeum w Kairze. K. Śliwa, Historia opowiedziana szeptem wachla$r z y \ldots$, https://muzea.malopolska.pl/czy-wiesz-ze/-/a/10191/historia-opowiedziana-szeptem-wachlarzy\%E2\%80\%A6 (dostęp: 08.05.2019).

${ }^{25}$ Strusie były ważnymi ptakami w starożytnym Egipcie, a ich pióra i jaja były cenione jako przedmioty luksusowe. Polowanie na strusie było królewskim sportem, który pozwalał królowi zademonstrować swoją kontrolę nad naturą. Był to substytut bitwy i jako taki był niebezpiecznym zajęciem. J. Tyldesley, 8 things you (probably) didn't know about Tutankhamun, www.historyextra. com/period/ancient-egypt/8-things-you-probably-didnt-know-about-tutankhamun/ (dostęp: 09.05.2019).

${ }^{26}$ Wachlarze tego typu były często przedstawiane na dekoracjach w grobowcach i mogły symbolizować „świętą obecność” faraona. Występują w grobowcach rodzin królewskich i wpływowych urzędników, ponieważ ruch flabellum był rozumiany (postrzegany) jako podtrzymujący oddech umarłemu. Były one także pomocne zmarłym w ich życiu pozagrobowym, które było oczywistą (dla potomnych) kontynuacją ich ziemskiej egzystencji (wędrówki), jakkolwiek wyrażoną w bardziej idylliczny sposób. Takie wachlarze były także regularnie (zwyczajowo) noszone przez uczestników królewskich procesji w pałacowych i religijnych obrzędach. Fans of Tutankhamun's tomb, www. fancircleinternational.org/history/fans-of-tutankhamuns-tomb/ (dostęp: 08.05.2019). 
Tutanchamona był mały $(18 \mathrm{~cm})$, wykwintny, obracający się wachlarz z kości słoniowej znaleziony w skarbcu, w pomalowanym na biało, drewnianym pudełku. Jego pióra, głównie białe z krótszym rzędem brązowych u podstawy, zachowały się w nienaruszonym stanie ${ }^{27}$.

Grecja. Kultura grecka zapożyczyła wachlarze od Egipcjan już ok. 1200 roku p.n.e. Początkowo były wykonywane ze sztywnych liści palmowych, trzciny czy pęków piór osadzonych na długim drążku. Używały go zarówno kobiety, jak i mężczyźni, jednak z racji jego dużych rozmiarów noszone były przez niewolników. Forma ta zaczęła się zmieniać w IV wieku p.n.e., kiedy to zmniejsza się rozmiar wachlarza, przez co stał się bardziej poręczny i można go było nosić osobiście. Zwykłe i najtańsze wachlarze robiono z gałązek mirtu, liści palmowych, cienkich deseczek, które z czasem ozdabiano; do wyrobu droższych używano malowanych i złoconych tkanin i skóry, które naciągano na drewniany stelaż lub naklejano na drewnie. Najczęściej spotykaną formą był wachlarz półkolisty ${ }^{28}$. W okresie hellenistycznym (323-30 p.n.e.) wykonywano także wachlarze z piór, którym często przypisywano właściwości magiczne. Najczęściej spotykaną formą był wachlarz w kształcie liścia lub półkolisty. W środkowej Grecji w Beocji, w Tanagrze odnaleziono polichromowane terakotowe figurki (300-200 p.n.e.) przedstawiające młode kobiety ubrane w chitony i himationy, z głowami przybranymi wieńcami, okryte szalami albo w kapeluszach. Trzymają one w rękach wachlarz, parasol, kwiat czy ptaka ${ }^{29}$. Odznaczają się wyrafinowaną kompozycją, doskonale uchwyconym ruchem i precyzją wykonania ${ }^{30}$. Figurki pełniły funkcje talizmanów lub wotów, które wkładano zmarłym kobietom do grobowców ${ }^{31}$.

Rzym. Wachlarze z piórami przymocowanymi do drążka występowały już u Etrusków ${ }^{32}$. Niewielkich wachlarzy - o formie sercowatej - częściej używały kobiety. Wyplatano je z ususzonych liści i gałązek, zwykle osadzane były na krótkiej rączce. $Z$ czasem w środku wachlarza umieszczano małe lusterko ${ }^{33}$.

Kultura starożytnego Rzymu opierała się na wzorach greckich i etruskich, skąd przejęła wzór wachlarza ceremonialnego, osadzonego na długim drzewcu. Wytworzyła też własny rodzaj wachlarza zwany paramosca (typ tzw.

${ }^{27}$ Wachlarz znajduje się w muzeum w Kairze; Fans of Tutankhamun's tomb (dostęp: 09.05.2019).

${ }^{28} \mathrm{M}$. Norenberg, Historia wachlarzy cz. 1 - ciepty powiew znad Śródziemnomorza, http://sztukkilka.pl/2017/05/14/historia-wachlarzy-cz-1/ (dostęp: 09.05,2019).

${ }^{29}$ Wiadomości o ubiorach greckich można znaleźć w opisach literackich, rzeźbach, a przede wszystkim w malowidłach na tzw. wazach greckich. E. Szyller, Historia ubiorów, Warszawa 1967, s. 27.

${ }^{30}$ Tanagryjskie figurki - niewielkie statuetki z terakoty (wysokość 7-25 cm), odkryte w grobach z końca IV i z III wieku p.n.e. w mieście Tanagra w Beocji (Grecja). Stownik terminologiczny sztuk pięknych, s. 410.

${ }^{31} \mathrm{~K}$. Schlansky, Wachlarz w kulturze europejskiej, w: Chłodny powiew wachlarzy. Wachlarz europejski od XVIII do XX w. Wystawa czasowa Muzeum Zamkowego w Pszczynie zorganizowana przy pomocy Kulturstiftung Dessau Wörlitz, 28 maja-30 listopada 2015, red. M. Kluss, Pszczyna 2015, s. 9.

${ }^{32}$ Etruria - tereny północnych Włoch, dzisiejsza Toskania.

${ }^{33}$ Schlansky, Wachlarz w kulturze europejskiej, s. 10. 
oganiaczka ${ }^{34}$ ), służący do oganiania się od owadów. Początkowo wachlarze z piór miały duże rozmiary i do noszenia ich niezbędni byli niewolnicy. $Z$ czasem ewolucja doprowadziła do ich zmniejszenia i patrycjuszki rzymskie posługiwały się nimi same. Materiały do wyrobu wachlarzy były takie jak w Grecji. Około IV wieku .n.e. pojawiła się nowa forma małego wachlarza w postaci chorągiewki ${ }^{35}$. Wachlarze-chorągiewki ${ }^{36}$ cieszyły się popularnością w Persji, a wytwarzano je $\mathrm{z}$ jednego kawałka tkaniny przymocowanej do metalowej ramki z uchwytem. Wielką popularność zyskały w renesansowych Włoszech, szczególnie w Wenecji. Wenecjanie specjalizowali się $\mathrm{w}$ ich produkcji. Chętnie używano strusich piór, które były sprowadzane z Afryki. Wachlarze wykonywano z różnorodnych materiałów naturalnych lub przetworzonych, takich jak słoma, bambus, drewno, papier, skóra, tkaniny czy pióra. Barwy najczęściej były neutralne, a dekorację stanowiła, wynikająca ze sposobu wytwarzania, plecionka lub wstawki z innych materiałów (np. miki); niekiedy wachlarz ozdabiany był koralikami lub malowany w różnego rodzaju wzory. Przybierał różne formy - począwszy od liścia, serca, koła lub jego części, prostokąta, gwiazdy czy chorągiewki ${ }^{37}$.

\section{Azja Południowa}

Indie. Najbardziej rozpowszechnionym rodzajem wachlarza w Indiach był typ wachlarza oganiaczki, który stanowił najprostszą formę i był najbardziej skuteczny w walce z natrętnymi owadami. Do jego wyrobu używano włosia z ogonów końskich i bydlęcych, różnego rodzaju traw i ptasich piór (szczególnie pawich). Pawie pióra były bardzo często stosowane do wachlarzy, którymi w Indiach i na Bliskim Wschodzie nadawano charakter symboliczny. Miało to związek z religią (w Indiach paw jest traktowany jako ptak święty), władzą, kultem bogactwa i płodności. Tworzono $\mathrm{z}$ nich ceremonialne wachlarze wielkich rozmiarów oraz małe wachlarzyki do codziennego, osobistego użytku. Częścią ozdobną oganiaczki była najczęściej rączka wykonana ze szlachetnych materiałów, takich jak: cenne metale, kość słoniowa, róg oraz egzotyczne drewna. Uchwyty te często były misternie rzeźbione i bogato dekorowane kamieniami szlachetnymi i masą perłową. W dużych pomieszczeniach stosowano specjalne wachlarze wielkich rozmiarów zwane punkah ${ }^{38}$. Wytwarzano je z liści, piór lub materiału, a służyły do wentylacji pomieszczeń. Wachlarzem poruszał służący poprzez pociąganie

\footnotetext{
${ }^{34}$ Oganiaczka - typ wachlarza nieskładanego, sztywnego.

${ }^{35}$ M. Selwa, Porozmawiajmy o wachlarzach, $c z .1$.

${ }^{36}$ Wachlarz-chorągiewka znany był już u Koptów. Schlansky, Wachlarz w kulturze europejskiej,
} s. 10.

${ }^{37}$ Jedną z najstarszych form wachlarza tego typu jest CHORĄGIEWKA, występująca w kulturze asyryjskiej, egipskiej, koptyjskiej i hinduskiej (buddyjskiej) oraz arabskiej (Północna Afryka). Zakon Wachlarza, http://salontradycjipolskiej.pl/zakon-wachlarza/ (dostęp: 11.05.2019).

${ }^{38}$ Słowo pankah wywodzi się z pankh, skrzydeł ptaka, które po trzepotaniu wytwarzają przeciąg. Punkah jest rodzajem wachlarza sufitowego używanego na subkontynencie indyjskim, stosowanym od początku VI wieku p.n.e.; Punkah wallah, https:/en.wikipedia.org/wiki/Punkah_wallah (dostęp: 11.05.2019). 
za specjalnie zamontowany system sznurów ${ }^{39}$. W swoim pierwotnym znaczeniu w Azji Południowej, punkah zazwyczaj wykonany był z pojedynczego liścia palmy lub tkanego kwadratu z bambusowych pasków, rattanu lub innego włókna roślinnego. W epoce kolonialnej wachlarz pod nazwą punkah był używany w Indiach Brytyjskich i innych częściach świata tropikalnego i subtropikalnego ${ }^{40}$.

\section{Azja Wschodnia}

Korea. Wszystkie źródła podają, że ojczyzną wachlarza jest Korea. Znane są wachlarze bojowe mubuchae (Hangul), które powstały za panowania dynastii Joseon; wtedy to zabroniono ludności posiadania mieczy i innej broni. Tymczasem takie wachlarze mogły być trzymane na widoku bez wzbudzania podejrzen ${ }^{41}$. Wyrabiane były z drewna pak dahl, niezwykle odpornego drzewa brzozowego, które rosło w lodowatych i surowych terenach górskich Półwyspu Koreańskiego. Pozyskiwano go $\mathrm{w}$ okresie zimowym, a następnie poddawano procesom hartowania, aby uzyskać jak największą twardość. Niektóre wachlarze przetykane były elastycznymi metalowymi paskami wzdłuż zewnętrznej krawędzi, tak aby uzyskać efekt ostrza i cięcia. Wytwarzano też bardzo przemyślne wachlarze, składających się z połączonych pojedynczych ostrzy, które po wyrzuceniu rozsypywały się, rażąc wielu przeciwników ${ }^{42}$. Jednak największą popularnością cieszył się wachlarz używany w tańcu zwanym Buchaechum ${ }^{43}$. Tancerze używają dużych wachlarzy pomalowanych w różowe kwiaty piwonii, a taniec do dnia dzisiejszego wykonuje się podczas dużych uroczystości. W czasie pokazu tancerze poprzez odpowiedni układ wachlarzy tworzą różne obrazy, np. ptaków, kwiatów, motyli czy fal ${ }^{44}$. Taniec ten jest wykonywany w grupie, głównie przez kobiety w tradycyjnym koreańskim stroju (Hanbok) i z tradycyjną koreańską muzyką.

Chiny. Wachlarze znano w Chinach już w pierwszym tysiącleciu p.n.e., gdzie najprawdopodobniej dotarły tam z Korei. Historia tworzenia tradycyjnych

${ }^{39} \mathrm{~W}$ Indiach i Pakistanie służący nazywali się punkach wallah. Najbardziej pożądani byli głusi, ponieważ zawsze byli w zasięgu słuchu poufnych rozmów. Tamże.

${ }^{40}$ Aby objąć większy obszar, na przykład w biurze lub w sądzie, pewna liczba punkahów mogła być połączona ze sobą za pomocą sznurków. Data tego wynalazku nie jest znana, ale była znana Arabom już w VIII wieku, choć wydaje się, że nie weszła do powszechnego użytku w Indiach przed końcem XVIII wieku; Punkah, https://en.wikipedia.org/wiki/Punkah (dostęp: 11.05.2019).

${ }^{41}$ Joseon - koreańskie państwo rządzone przez dynastię Yi, zapoczątkowaną przez króla Taejo Yi Seong-gye. Istniało przez ponad pięć wieków, od 1392 do 1897 roku. Joseon, https://pl.wikipedia.org/wiki/Joseon (dostęp: 21.05.2019).

${ }^{42}$ Często też ukrywały śmiercionośne trucizny lub oszałamiające mikstury w pęcherzach lub kanałach, które otwierały się po wyrzuceniu wachlarza, pozwalając użytkownikowi delikatnie skierować podmuch czynników drażniących i toksyn na przeciwnika w niewielkiej odległości. Korean fighting fan, https://en.wikipedia.org/wiki/Korean_fighting_fan (dostęp: 21.05.2019).

${ }^{43}$ Buchaechum to tradycyjna forma tańca koreańskiego, zwana również tańcem z wachlarzami, zwykle wykonywana przez grupy koreańskich tancerek. Buchaechum, https://en.wikipedia.org/wiki/Buchaechum (dostęp: 21.05.2019).

${ }^{44}$ Taniec odrodził się także w nowym znaczeniu; wiązało się to z szamańskimi przekonaniami o naturze i jej naturalnym ruchu. Buchaechum-Korea. The fan dance, https://danceask.com/buchaechum-korea/ (dostęp: 21.05.2019). 
chińskich wachlarzy sięga czasów okresu Heian ${ }^{45}$. Wczesne wachlarze były wytwarzane $\mathrm{z}$ pór ptasich (chiński znak dla słowa wachlarz ma takie samo znaczenie, jak słowo pióro). Później wyrabiano je z papieru, jedwabiu i ptasich piór, bambusa, szylkretu ${ }^{46}$, kości słoniowej, drewna i metali. Wiele wachlarzy było wysokiej wartości artystycznej - były dekorowane i zdobione cennymi materiałami i malowane przez twórców o wybitnych umiejętnościach. Przeznaczone były dla bogatszego, wysoko postawionego odbiorcy, zarówno dla mężczyzn, jak i kobiet. Wyróżniały się wspaniałymi zdobieniami, kaligrafowano na nich teksty poetyckie, a niektóre były zdobione kamieniami szlachetnymi ${ }^{47}$. Wachlarze były także poświęcane bogom, aby odpędzały złe moce. Występowały jego dwie tradycyjne formy: jedna sztywna, w kształcie zaokrąglonego kwadratu, wykonana ze słomy a nawet z piór, zwana Ping Shan, była najbardziej powszechna w Chinach ${ }^{48}$ aż do końca dynastii Song ${ }^{49}$; druga, składana, wytwarzana z papieru, jedwabiu lub drzewa sandałowego, znana pod nazwą Zhe $S h a n^{50}$, rozpowszechniła się już w czasie dynastii Ming ${ }^{51}$. Mimo to można wyróżnić pięć typów chińskich wachlarzy: Zhensi - wykonany z prawdziwego jedwabiu; Tanxiang - z drzewa sandałowego; Huohua - pochodzący z dynastii Qing ${ }^{52}$, wykonany z malowanego szkła; Zhusi - okrągły kształt wachlarza, wykonany z przędzy bambusowej drobno tkanej, nadającej mu przezroczysty wygląd skrzydeł cykady; Lingjuan - składany $\mathrm{z}$ użyciem muślinu z jasnego jedwabiu. Wachlarze nasączano wonnymi olejkami, aby wytwarzały „wonny wietrzyk" ${ }^{53}$. W dawnych czasach używano wachlarzy do utrzymania świeżości powietrza i ochrony przed światłem słonecznym i kurzem. Jakość i kształt wachlarza był oznaką statusu społecznego, w pewnym okresie świadczyły o randze urzędnika cesarskiego ${ }^{54}$.

${ }^{45}$ Heian - okres w historii Japonii trwający od 794 do 1185 roku. Types of japanese fans, https://www.theclassroom.com/types-of-japanese-fans-12080883.html (dostęp: 11.05.2019).

${ }^{46}$ Szylkret, masa rogowa okrywająca tarczę grzbietową żółwia morskiego, przejrzysta, o ciepłej lekko żółtawej barwie z ciemnymi cętkami. Stownik terminologiczny sztuk pięknych, s. 405.

${ }^{47}$ Sztywne reguły odnośnie kształtu wachlarza i zasad jego używania obowiązywały dwór cesarski i całą strukturę urzędniczą państwa. Przy zachowaniu wszelkich reguł, wachlarz był jednak przedmiotem bardzo pomocnym w obejściu etykiety, gdyż np. zasłaniając nim twarz, można było uniknąć niekończących się, ceremonialnych ukłonów. Innym zastosowaniem praktycznym było posługiwanie się wachlarzem przy karceniu uczniów w szkole bądź regulowanie przez sędziego na ringu przebiegu zapasów sumo. Selwa, Porozmawiajmy: o wachlarzach, cz. 1 .

${ }^{48}$ Wachlarze te były popularne w całej Azji, w tym w Birmie, Tajlandii, Kambodży i na Sri Lance.

${ }^{49}$ Dynastia Song - dynastia panująca w Chinach od 960 do 1279 roku.

${ }^{50}$ Odmiana wachlarza składanego typu brisé.

${ }^{51}$ Dynastia Ming - dynastia cesarska Chin, panująca od 1368 do 1644 roku.

${ }^{52}$ Dynastia Qing - ostatnia dynastia cesarska Chin, nazywana też dynastią mandżurską, panująca w latach 1644-1912.

${ }^{53}$ Fans, www.comuseum.com/culture/fans/ (dostęp: 11.05.2019).

${ }^{54}$ Chinese fans, https://www.fancircleinternational.org/history/chinese-fans/ (dostęp: 11.05.2019). 
Japonia. Wachlarze mają długą historię w Japonii i zgodnie z legendą kraj ten jest ojczyzną nowoczesnego składanego wachlarza. Najwcześniejsze dowody istnienia wachlarzy w Japonii odkryto w malowidłach ściennych kopca pogrzebowego z VI wieku w Fukuoce ${ }^{55}$. Przedstawiały one wachlarz ceremonialny w stylu chińskim. W tym okresie wpływy chińskie były silne w Japonii, a wachlarze wzorowane były na wachlarzach z okresu Heian w Chinach, które przybyły wraz z poselstwami i szybko rozprzestrzeniły się na dworze cesarskim i wśród ludności. Najbardziej popularna w Chinach i Japonii była odmiana wachlarza składanego typu brisés6. Do jego wyrobu stosowano różnorodne materiały, a stelaż był z reguły misternie rzeźbiony w drobne ornamenty roślinne, pejzażowe, detale architektoniczne oraz ludzkie postacie. Ze względu na gorące i wilgotne lato wachlarze doskonale nadawały się - zarówno dla kobiet, jaki i dla mężczyzn - do ochłody ${ }^{57}$. Zaczęły być powszechnie stosowane i spełniały wielorakie funkcje, m.in. jako atrybut urzędnika, nauczyciela, tancerki, gejszy, młodego mężczyzny czy wojownika ${ }^{58}$. Stał się cechą kobiecości lub męskości w zależności od koloru i sposobu trzymania podczas wachlowania ${ }^{59}$. Wśród najstarszych japońskich wachlarzy można wyodrębnić dwa typy: sztywny, okrągły, wykonany z piór lub jedwabiu rozciągniętego na okrągłej lub owalnej ramie i drugi - wachlarz ceremonialny. Różnił się on zasadniczo tym, że miał większy rozmiar, był zamontowany na długim trzonku i używany przez uczestników ceremonialnej świty wysokich urzędników przy sprawowaniu ważnych funkcji lub w procesjach. Około VIII wieku Japonia staje się ojczyzną wachlarzy składanych. Wykonane były ze sztywnych segmentów zaczepionych razem u podstawy za pomocą nitu i łączonych na górze nitką lub wstążką. Według legend - zarówno chińskich, jak i japońskich - składany wachlarz został wymyślony przez urzędnika sądowego, który połączył cienkie klepki z drewna lub kości słoniowej, które wszyscy urzędnicy nosili w celu pisania, tworząc w ten sposób pierwszą formę prymitywnego wachlarza typu brisé, zwaną po japońsku Mokkan. Inna legenda towarzysząca temu wynalazkowi opowiada o kłótliwych małżonkach, do mieszkania których wpadł nocą nietoperz. Zwierzę opaliło sobie nad lampą skrzydło i upadło na podłogę. Podnosząc je, mężczyzna zauważył,

\footnotetext{
${ }^{55}$ Fukuoka - największe miasto japońskiej wyspy Kiusiu, leżące w jej północnej części.

${ }^{56}$ Konstrukcja wachlarza brisé skłaniała do zastosowania nowinek technologicznych i tworzenia wachlarzy-zabawek (np. tzw. „łamiące się”), umieszczano na nich przenikające się na przemian i znikające kompozycje, często o tematach erotycznych. Japonia zasłynęła m.in. ze sztuki zastosowania w dekoracji wachlarzy metali (miedzi, brązu, srebra i złota), inkrustacji ozdobnymi kamieniami i emalią. Selwa, Porozmawiajmy: o wachlarzach, cz. 1.

${ }^{57}$ Produkowano wachlarze nieskładane i składane, ceremonialne i zwyczajne, codziennego użytku oraz wachlarze sygnałowe. M. Kotliński, Wachlarz jako atrybut - wachlarz jako broń, https://japonia-online.pl/article/443 (dostęp: 09.05.2019).

${ }^{58}$ Dlatego też wachlarz otrzymał wiele adekwatnych określeń: uchiwa, dansen (nieskladane), sensu, ogi (wachlarze składane - osobiste), shaku (wachlarz dworski), tessen, gunsen (wachlarze bojowe - wzmacniane), gumbai-uschiwa (wachlarz sygnałowy). Tamże.

${ }^{59}$ S. Mol, Broń dawnej Japonii. Specjalne rodzaje broni $i$ sposoby ich wykorzystania, Bydgoszcz 2004, s. 82.
} 
jak ono jest zbudowane i że jego skrzydło składa się i otwiera. Obserwacja ta posłużyła do sporządzenia wachlarza składanego, którego najstarsze formy noszą nazwę komori, co oznacza nietoperza. Inna historia wspomina przypadkowy wynalazek składanego wachlarza - pewna wdowa, która przeszła na emeryturę do świątyni Mieido w Kioto, wyleczyła z gorączki opata, wypowiadając zaklęcia i wachlując go kawałkiem papieru złożonym w plisy ${ }^{60}$.

Zasadniczo rozróżnia się trzy warianty japońskich wachlarzy: nieskładany (sztywny), składany i wojenny (bojowy). W każdym z wariantów różnią się kształtem i przeznaczeniem.

Wachlarz osobisty, nieskładany - uchiwa, dansen - sklasyfikowano jako japoński, ale uważa się, że pochodzi z Chin. Wachlarz płaski i sztywny używany był jako wachlarz osobisty lub do celów dekoracyjnych. Tradycyjnie składa się on $\mathrm{z}$ okrągłej ramy wykonanej z rozszczepionego w wąskie drzazgi bambusa. Następnie na ramkę naciąga się jedwab lub papier washi $i^{61}$, malowany zazwyczaj w piękne i skomplikowane wzory ${ }^{62}$.

Wachlarz osobisty, składany - sensu, ogi - jest używany podczas różnych ceremonii (np. ceremonii picia herbaty) i powszechnie uznaje się jego japońskie pochodzenie. Rozwinęło się wiele odmian wachlarza sensu. Dla kobiet są wytwarzane wachlarze wielkości od 18 do $20 \mathrm{~cm}$, a dla mężczyzn od 23 do $24 \mathrm{~cm}$. Oryginalny sensu składał się ze składanej ramy wykonanej z bambusa pokrytej japońskim papierem washi. Wytwarzany był już w Chinach w okresie Heian. Ögi składał się z dużej liczby łopatek drewnianych, zwykle między 34 i 38 , połączonych z metalowym nitem. Tło wachlarza było pomalowane jasnymi kolorami ze starannie dobranymi wzorami sosen, chryzantem lub kwiatów wiśni, a czasem ptaków, na białym podłożu, otoczonych stylizowanymi chmurami ze złota i srebra, różnie zarysowanymi czerwonymi, niebieskim, zielonymi i fioletowymi barwami. Od góry z każdej łopatki zwisały wiązki sztucznych kwiatów i długie jedwabne sznurki w różnych kolorach. Dla osób poniżej 16 roku życia ōgi był wykonany $\mathrm{z}$ cedru zamiast $\mathrm{z}$ drewna cyprysowego ${ }^{63}$.

${ }^{60}$ Japanse fans, https://www.fancircleinternational.org/history/japanese-fans/ (dostęp: 11.05.2019).

${ }^{61}$ Washi to tradycyjny papier japoński, który wpisany jest na listę niematerialnego dziedzictwa kulturowego UNESCO. Jest on bardziej wytrzymały od zwykłego papieru, dlatego znajduje zastosowanie w wielu różnych dziedzinach, m.in. w produkcji lampionów, wachlarzy, parasoli, jak również w kaligrafii czy origami.

${ }^{62} \mathrm{~W}$ dzisiejszych czasach wachlarze uchiwa mają zastosowanie marketingowe lub jako reklama $\mathrm{z}$ hasłami. Stało się tak dlatego, że są najłatwiejszą formą w masowej produkcji. Tak powstaje washi - tradycyjny, ręcznie robiony papier japoński, http://dziwowisko.pl/washi-papier-japonski/ (dostęp: 15.05.2019).

${ }^{63}$ Japanese fans, (dostęp:09.05.2019). 
Wachlarz teatralny, składany - chukei lub noh (składany) - wytwarzany jest z prostych bambusowych kijów i malowanego papieru, naklejonego na drewniane listewki, i używany w teatrze $N \tilde{o}^{64}$ i $\mathrm{Kabuki}^{65}$. Ten wachlarz przeszedł różne zmiany na przestrzeni wieków. Całość spektaklu wspierana jest przez użycie symbolicznych rekwizytów, z których najważniejszy jest wachlarz. Służy on do podkreślania ekspresji ruchu i ukazywania emocji. Tak właśnie używa się wachlarza podczas występów japońskiego teatru Kabuki66.

Wachlarz dworski, składany - shaku - noszony był przez damy i dworzan. Zwyczajem stało się, że dworzanie zasłaniali sobie usta podczas rozmowy $\mathrm{z}$ cesarzem. Mógł on być wykonany z materiału według rangi posiadacza: władcy używali jadeitu, szlachta używała kości słoniowej, a urzędnicy sądowi bambusa. Japońskie shaku zwykle wykonane było z drewna, takiego jak cis japoński, ostrokrzew, wiśnia lub cedr japoński ${ }^{67}$.

Wachlarz bojowy (żelazny), składany - tessen, menbarigata tessen - noszony na co dzień i używany w walce, był wykonany z metalu lub nim wzmocniony. Przysługiwał oficerom niższej rangi i niezbyt różnił się od zwykłego wachlarza. Zrobiony był ze złożonego arkusza pergaminu, z wymalowanym słońcem heraldycznym Japonii, rozpiętego na metalowych piórach i wzmocniony metalowymi okładzinami ${ }^{68}$. Samurajowie mogli zabrać je do miejsc, w których miecze lub inne jawne bronie nie były dozwolone. Tessen był również używany jako rodzaj maczugi, a także do odpierania ciosów oraz jako broń do rzucania ${ }^{69}$. Wytwarzano też egzemplarze nieskładane, znane jako tenarashi. Menbarigata tessen to składany wachlarz, którego zewnętrzne żeberka były wykonane z żelaza, a wewnętrzne $\mathrm{z}$ bambusa, choć czasem i one były z żelaza lub mosiądzu. Żeberka łączono tradycyjnym japoński papierem washi, często lakierowanym lub pokrytym złotą lub srebrną folią. Połączone były nitem, do którego doczepiano jedwabny sznur, aby samuraj mógł go sobie owinąć wokół dłoni. Mniejsze egzemplarze mierzyły ok. $21 \mathrm{~cm}$, a większe ponad $51 \mathrm{~cm}$. W Japonii do dzisiaj funkcjonuje wiele szkół, w których można przyswoić wiele dawnych technik posługiwania się wachlarzami ${ }^{70}$.

\footnotetext{
${ }^{64} N \tilde{o}, n \bar{g} g a k u$ - jeden z głównych gatunków dramatu japońskiego, klasyczny teatr Japonii, łączy dramat, pieśn i taniec. Tamże.

${ }^{65} \mathrm{Kabuki}$ - jeden z trzech głównych rodzajów tradycyjnego teatru japońskiego, wywodzący się z XVII wieku. Tamże.

${ }^{66}$ Ponieważ większość mówionego słowa w tego typu teatrze jest niezrozumiała dla przeciętnego Japończyka, wachlarz jest używany przez aktora do akcentowania prawie każdego gestu w całym dramacie i wskazywania publiczności, poprzez manipulację i znaczenia symboliczne, co się dzieje. Tamże.

${ }^{67}$ Mol, Broń dawnej Japonii, s. 82.

${ }^{68}$ Z. Żygulski jun., Broń wschodnia, Warszawa 1986, s. 173.

${ }^{69} \mathrm{https}$ ://en.wikipedia.org/wiki/Japanese_war_fan (dostęp: 09.05.2019).

${ }^{70} \mathrm{Mol}$, Broń dawnej Japonii, s. 81-85.
} 
Na polu bitwy posługiwano się ciężkimi nierozkładanymi wachlarzami gunbai $^{71}$ lub rozkładanymi - gunsen ${ }^{72}$, które służyły zarówno do ochłody, jak i kierowania żołnierzami. Wachlarze gunbai były różnych rozmiarów i kształtów, wykonane $\mathrm{z}$ drewna zwykłego lub lakierowanego, z metalowymi elementami dekoracyjnymi albo bez nich, lub z litego metalu. Często były ozdobione symbolami, takimi jak herb rodzinny lub slogany czy inwokacje do różnych bogów. W przeciwieństwie do gunbai, gunsen, można było je rozkładać jak zwykłe wachlarze. Najczęściej wykonywano je z drewna i papieru, tylko w niektórych egzemplarzach zewnętrzne żeberka robiono z żelaza. Określały one także rangę dowódcy. Oba te typy wachlarzy były bardzo solidnej budowy, z powodzeniem mogły służyć do odparowywania ciosów ${ }^{73}$.

\section{Europa nowożytna}

Już w średniowiecznych inwentarzach odnotowywano liczbę wachlarzy oraz materiały, z których je wykonywano. W tych czasach najpopularniejszymi modelami były: na terenie Bizancjum - wachlarz kolisty, a na półwyspie Apenińskim - wachlarz chorągiewkowy, który chętnie stosowano także w okresie renesansu na równi z pierzastymi wersjami. Były to wachlarze sztywne nieskładane. Wśród kobiet rozpowszechniły się wachlarze przypinane łańcuszkiem do pasa sukni, natomiast większymi odmianami wachlowali je służący ${ }^{74}$. W tym okresie wachlarze w formie ekranu ${ }^{75}$ były przedmiotami użytku codziennego. Wykonywano je z różnych materiałów naturalnych lub przetworzonych, takich jak słoma, bambus, drewno, papier, skóra, tkaniny czy pióra. Występowały w barwach naturalnych, gdzie dekorację stanowiła, wynikająca ze sposobu wytwarzania, plecionka, bądź były barwione, uzupełniane wstawkami z innych materiałów (np. miki), haftowane koralikami, malowane w różne ornamenty. Takie wachlarze spotykano w Azji (w szczególności w Indiach), w Afryce i w Południowej Ameryce. Jedną z najstarszych form wachlarza tego typu jest chorągiewka, występująca w kulturze asyryjskiej, egipskiej, koptyjskiej i hinduskiej (buddyjskiej), oraz arabskiej (Północna Afryka) ${ }^{76}$. Najczęściej były to wachlarze w formie tarczy lub koła. Nowością były wachlarze przeznaczone dla chorych, których zadaniem było odpędzanie zepsutego powietrza ${ }^{77}$. Kolejna

${ }^{71}$ Gunbai-uschiwa (wachlarz sygnałowy) - używany w czasie wojny przez dowódcę wojska, obecnie gunbai trzymany jest przez sędziego w walkach sumo. Tamże, s. 82.

${ }^{72}$ Gunsen był wachlarzem składanym stosowanym przez generałów, samurajów i urzędników dworskich, nieuważanym za broń, ale jako środek sygnalizacji podczas bitwy. Tamże.

${ }^{73}$ Tamże, s. 82-83.

${ }^{74}$ Norenberg, Historia wachlarzy, (dostęp: 03.06.2019).

${ }^{75}$ Ekran - typ wachlarza sztywnego, nieskładanego, który przybierał różne formy - począwszy od liścia, serca, koła lub jego części, prostokąta, gwiazdy, chorągiewki itd. Ciekawostkę stanowi okoliczność, że do formy chorągiewki powrócono w epoce włoskiego renesansu. Selwa, Porozmawiajmy o wachlarzach, cz. 1 .

${ }^{76}$ Norenberg, Historia wachlarzy, (dostęp: 03.06.2019).

${ }^{77}$ Lekarze brali go ze sobą, udając się do chorych dla rozpędzania nieczystego powietrza. S. Kosieliński, Spojrzenie zza wachlarza, „Wiedza i Życie”, (1997) nr 1, s. 44. 
fala powodzenia i stosowania wachlarzy związana była z wyprawami i wojnami krzyżowymi ${ }^{78}$. Widać tu wyraźnie wpływ obyczajów Bliskiego Wschodu. Ornament wachlarza pojawia się w heraldyce - np. król Ryszard Lwie Serce umieścił wachlarz w swoim herbie. Za królem podążają inni - i tak spotykamy wachlarze we wzorach pieczęci książęcych tego czasu (koniec XII w.).

Gdy portugalscy żeglarze powracali z wypraw na Daleki Wschód, przywozili różne przedmioty użytku codziennego - wśród nich znajdowały się składane wachlarze, zupełnie do tej pory $\mathrm{w}$ Europie nieznane. Wachlarz składany konstruowany był na stelażu wykonanym z wielu piór (listewek), z materiałów, takich jak: kość słoniowa, szylkret, róg, drewno lub metal. Listewki u dołu połaczone były małym nitem ${ }^{79}$, a pokrycie stanowił papier lub pergamin. Po 1780 roku jako pokrycie stosowano jedwab i koronki ${ }^{80}$. Ta forma wachlarza szybko się spopularyzowała i zaczęła wypierać panujące dotychczas typy ekranu i oganiaczki, w tym szczególnie, ulubione i modne, wachlarze z piór oraz chorągiewki. Wachlarz składany, praktyczny i poręczny, szybko podbił serca Europejek. W rozpropagowaniu tego przedmiotu w dużej mierze było zasługą Katarzyny Medycejskiej ${ }^{81}$, która nowy gadżet zabierała ze sobą w każdą podróż. We Włoszech chętnie stosowano strusie pióra sprowadzane z Afryki, które używane były jako pióra ${ }^{82}$ okładzinowe lub ułożone w formę bukietu, mocowane na uchwycie bogato zdobionym ${ }^{83}$. W XVI wieku wachlarz staje się modny na dworze królowej Anglii Elżbiety I ${ }^{84}$. Wachlarze monarchini były luksusowe, zdobione metalami i kamieniami szlachetnymi. W XVI i XVII wieku w Niderlandach popularne były także wachlarze z piór, a powodem tego była ożywiona żegluga na Daleki Wschód. Importowano stamtąd piękne pióra marabutów i strusi. Przedmioty te stały się obowiązkowym dodatkiem do kobiecych strojów ${ }^{85}$. Na początku największym zainteresowaniem cieszyły się wśród kobiet, ale i mężczyźni wykazywali nimi zainteresowanie. „Męskie” wachlarze wytwarzano jeszcze w XVIII wieku i były dość charakterystyczne ${ }^{86}$. Wachlarz stał się modnym i niezbędnym dodatkiem stroju

${ }^{78}$ Rycerze umieszczali motyw wachlarza w herbach i na proporcach. Przywozili także z wypraw wachlarze jako dary. Tamże.

${ }^{79}$ Wachlarz już nie miał uchwytu, czyli dłuższej rączki.

${ }^{80}$ Schlansky, Wachlarz w kulturze europejskiej, s. 13.

${ }^{81}$ Katarzyna Medycejska (1519-1589) - królowa Francji, żona Henryka II Walezjusza.

${ }^{82}$ Pióra często barwiono tak, aby wachlarz z piór pasował do sukni.

${ }^{83}$ Schlansky, Wachlarz w kulturze europejskiej, s. 11.

${ }^{84}$ Elżbieta I (1533-1603) - królowa Anglii i Irlandii, córka Henryka VIII i jego drugiej żony Anny Boleyn, była wielką miłośniczką tych przedmiotów, ogłosiła chęć otrzymywania darów w postaci wachlarzy. Podczas inwentaryzacji po jej śmierci doliczono się ich ok. 300. Większość została podarowana przez mieszkańców Londynu. Na wielu portretach Elżbieta I została namalowana $\mathrm{z}$ wachlarzami.

${ }^{85}$ Niderlandzcy malarze na swoich obrazach uwiecznili zamiłowanie bogatych dam do czarnych jedwabnych, atłasowych lub bawełnianych strojów z białymi kołnierzykami i mankietami do małych wachlarzy ze strusich piór. Schlansky, Wachlarz w kulturze europejskiej, s. 11.

${ }^{86}$ Obrazek na materiale czy papierze przedstawiał zawsze robaka - żuka albo muchę. Nie wiadomo, dlaczego tak zdobiono. S. Gieżyński, Wachlarz - kobiece berto, https://www.weranda.pl/ sztuak-new/kolekcje-new/wachlarz-kobiece-berlo (dostęp: 27.05.2019). 
kobiecego i na tyle popularnym „narzędziem”, że zaczęły powstawać ośrodki ich produkcji. Jako nowo powstała gałąź rzemiosła, jaką było wytwarzanie wachlarzy, miała szczęście do przywilejów państwowych. Już w XVI wieku, w 1594 roku, król Henryk IV wydał przywilej dla nowo powstałej organizacji pod nazwą „Paryska Korporacja Wytwórców i Dekoratorów Wachlarzy”87. Rozwój tego rzemiosła odpowiadał na zapotrzebowanie, które wciąż rosło. Pod koniec XVII wieku w Paryżu znajdowało się ok. 500 warsztatów wytwarzających wachlarze. W 1673 roku pod patronatem króla Ludwika IV powstało „Stowarzyszenie Wytwórców Wachlarzy", które ustalało zasady i warunki uzyskania zawodu oraz odpowiadające im normy prawne. Organizację tego typu posiadała również Anglia - w 1709 roku został wydany przez królową Annę akt założycielski „Towarzystwa Wytwórców Wachlarzy”. Jako ciekawostkę należy odnotować fakt, że znaczna część angielskich wytwórców wachlarzy wywodziła się z Francji ${ }^{88}$. W 1755 roku Towarzystwo liczyło już 883 członków. We Włoszech najbardziej znane ośrodki produkcji wachlarzy to Mediolan, Genua i Siena, gdzie wytwarzano wachlarze z piór strusich, pawich, kruczych, a także, co stanowi nowość, z kolorowych piór papug o długich ogonach. Uchwyty wykonano z rzeźbionej kości słoniowej, ze złota lub srebra, wysadzanych kamieniami ozdobnymi. Zaopatrzone były w łańcuszek lub wstążkę, aby można było przymocować go do ubioru. Wenecja słynęła z artystycznych wachlarzy - chorągiewek, noszonych przez arystokratki i kobiety bardzo zamożne. Te wykonane z białego welinu i ozdobione wenecką koronką przeznaczone były dla zaręczonych dziewcząt. W Neapolu i Bolonii przeważały sztywne wachlarze typu ekran, dekorowane geometrycznymi wzorami. We Florencji i Parmie także odmiennie ozdabiano te przedmioty. Natomiast rzemieślnicy w Ferarze wymyślili swoisty typ wachlarza zwany kurza tapka. Zwykle wykonany był z welinu ${ }^{89}$ i drobinek przymocowany do stelażu z kości słoniowej. Pod koniec XVIII wieku moda na owe przedmioty obejmuje już niższe warstwy społeczne i w związku z tym ich produkcja nabiera charakteru masowego. Od samego początku europejskie wachlarze były bogato dekorowane. Ich wyrobem trudnili się perfumiarze, ale już w XVII wieku na dworze francuskim pojawił się cech wachlarzników ${ }^{90}$. Ich ulubionym materiałem do produkcji tych przedmiotów były pióra, misternie wycinany pergamin i papier, klejnoty i szlachetne metale. Na początku przeznaczone były i dla kobiet, i dla mężczyzn. Męskie wachlarze były bardzo charakterystyczne ${ }^{91}$ i spotkać je można było jeszcze w XVIII wieku. Bogato zdobione wachlarze budziły początkowo zainteresowanie tylko koronowanych głów, ponieważ były zbyt kosztowne, aby mogły być powszechnie używane ${ }^{92}$.

${ }^{87}$ M. Selwa, Porozmawiajmy: o wachlarzach, cz.2, https://kolekcjonersurowcow.wordpress. com/2011/12/20/porozmawiajmy-o-wachlarzach-cz-2/ (dostęp: 01.06.2019).

${ }^{88}$ Byli to uciekinierzy przed prześladowaniami religijnymi. Tamże.

${ }^{89}$ Welin - bardzo cienki pergamin z cielęcej skóry, wysokiej jakości.

${ }^{90}$ Selwa, Porozmawiajmy: o wachlarzach, cz. 2.

${ }^{91} \mathrm{Na}$ materiale lub papierze malowano zawsze robaka - żuka albo muchę. Gieżyński, $\mathrm{Wa}$ chlarz-kobiece berto.

${ }^{92}$ Kosieliński, Spojrzenie zza wachlarza, s. 44. 
Drugim rodzajem wachlarza bez uchwytu, który także przybył z Azji Wschodniej i zyskał popularność na równi z wachlarzem składanym, był wachlarz płytkowy zwany brisé. Tworzyły go pióra (płytki) wykonane z różnych materiałów, ułożone w kształt klina i połączone ze sobą wstążką, a u dołu spięte małym nitem. Płytki z kości słoniowej czy drewna były zdobione dekoracjami snycerskimi, ażurowymi, malarskimi, aplikacjami oraz złoceniami ${ }^{93}$.

W XVII i XVIII wieku nastały złote czasy wachlarzy. Królowały w salonach wyższych sfer i na dworach królewskich całej Europy. Stały się symbolem dostatku, wykwintności i kokieterii bez względu na porę roku. Wachlarz stał się atrybutem damy na dworze królewskim czasów Króla Słońce ${ }^{94}$, gdzie kultywowano ars amandi $i^{95}$, a przedmiot ten staje się najwspanialszym instrumentem tej sztuki. Powstał więc sekretny język wachlarzy ${ }^{96}$, który musiała opanować każda młoda kobieta wchodząca na salony. Posługiwanie się tym przedmiotem stało się odtąd sztuką, którą musiały przyswoić sobie wchodzące w świat panny. Mowa znaczących gestów, która narodziła się w Hiszpanii, a udoskonalona została we Francji, stała się kodem flirtu i intryg dworskich. XVIII wiek - nazywany stuleciem kobiet był okresem wyrafinowanej gry towarzyskiej. To wówczas narodził się bon mot, iż w rękach prawdziwej piękności wachlarz jest „,berłem pozwalającym jej władać światem"97. Wiele wachlarzy było małymi dziełami sztuki, na których pojawiały się scenki rodzajowe, alegorie cnót, biblijne, a nawet ważniejsze wydarzenia historyczne, malowane przez wielkich artystów epoki, m.in. Antoine'a Watteau ${ }^{98}$, François Bouchera ${ }^{99} \mathrm{i}$ innych. Słynna markiza de Pompadour była podobno pomysłodawczynią tzw. wachlarza domino, z wyciętymi otworami, przez które dama mogła obserwować otoczenie, sama pozostając nierozpoznawalna. Z kolei w wachlarzu używanym przez Marię Antoninę ${ }^{100}$ zamontowano soczewkę, która służyła królowej jako okulary ${ }^{101}$. Okres baroku ${ }^{102}$ to czas, kiedy w sztuce następuje

${ }^{93}$ Schlansky, Wachlarz w kulturze europejskiej, s. 13.

${ }^{94}$ Żygulski jun, Kostiumologia, s. 151.

${ }^{95}$ Sztuka kochania - ars amandi na wzór Owidiusza i prowansalskich trubadurów. Tamże s. 45.

${ }^{96}$ Odpowiednie poruszanie wachlarzem przerodziło się w sekretny język, pełen aluzji, w którym kochankowie mogli wyrażać stan swoich uczuć. Odpowiednie manipulowanie nim stało się ustalonym kodem informującym kochanków o ich zamiarach. Kosieliński, Spojrzenie zza wachla$r z a$, s. 46.

${ }^{97} \mathrm{~J}$. Siemionowa, Wachlarz, który mówi, https://wiadomosci.onet.pl/kiosk/wachlarz-ktory-mowi/30cg3 (dostęp: 01.06.2019).

${ }_{98}$ Antoine Watteau (1684-1721) - francuski malarz, rysownik i rytownik, prekursor i czołowy przedstawiciel francuskiego rokoka.

${ }^{99}$ François Boucher (1703-1770) - francuski malarz, grafik i dekorator, jeden z najbardziej znanych przedstawicieli rokoka.

${ }^{100}$ Śliwa, Historia opowiedziana szeptem wachlarzy...

${ }^{101}$ Karnawat i jego rekwizyt, Muzeum w Kozłówce, http://muzeumzamoyskich.historia.org. pl/2015/01/29/karnawal-i-jego-rekwizyt/ (dostęp: 01.06.2019).

${ }^{102}$ Barok - główny kierunek w kulturze europejskiej, którego trwanie datuje się od końca XVI do XVIII wieku. 
wielkie upodobanie motywu wachlarza. Pojawia się on w architekturze jako ozdobny detal oraz $w$ introligatorstwie ${ }^{103}$. Oprócz wytwórni rodzimych, wachlarze w surowym stanie, ale też gotowe, importowano z Chin i Japonii i dopiero na miejscu (w Europie) były ozdabiane.

W XVIII i XIX wieku można było spotkać wachlarze typu aide-mémoire, czyli pewnego rodzaju przypominajki. Od wewnętrznej strony miały wypisane teksty popularnych piosenek, układy kroków tanecznych czy zasady gier towarzyskich lub karcianych. W teatrach i na balach rozdawano programy wypisane na listkach wachlarza. Ciekawy sposób wykorzystania tego przedmiotu pojawił się podczas Rewolucji Francuskiej, kiedy to mieszczki paryskie umieszczały na nich hasła rewolucyjne. Interesującym rozwiązaniem użycia wachlarza było wmontowywanie pomiędzy listewki soczewek, które pozwalały przyglądać się towarzystwu obok, a także ułatwiały czytanie. W teatrach, salonach i salach balowych panie prezentowały najnowsze modele, a wachlarz stał się niezbędnym środkiem w komunikacji. Osiemnastowieczni malkontenci głośno narzekali, że wszędzie, słychać „szept wachlarzy, szum wachlarzy i kłótnie wachlarzy”104. Ten kod kulturowy był na tyle skomplikowany, że młodym pannom z dobrych domów zalecano zajęcia pomagające w jego opanowaniu. W Londynie w połowie XVIII wieku otworzono nawet „Akademię sztuki posługiwania się wachlarzem dla szlachetnie urodzonych" 105 . Niewątpliwie mogło się do tego przyczynić podarowanie przez cesarza Chin dworowi angielskiemu aż 240 wachlarzy wspaniale zdobionych kamieniami szlachetnymi ${ }^{106}$.

Pod koniec XVIII wieku pojawił sięnowy typ wachlarza-konwersacyjny, który był używany aż do XX wieku. Popularny był zwłaszcza we Włoszech (szczególnie w Wenecji), Francji, Anglii i Hiszpanii. Wachlarze takie zawierały przemyślne zdania wraz z aluzjami i symbolicznymi obrazkami, a poprzez odpowiedni układ cyfr ukrytych w pejzażu można było tworzyć wyrafinowane dialogi. W 1795 roku paryżanki zaczęły używać wachlarza nazwanego telegraficznym, ponieważ skrywał znaki, z których układano słowa ${ }^{107}$. W Hiszpanii, a zwłaszcza

${ }^{103}$ Oprawa wachlarzowa (z fr. éventail) - motyw dekoracyjny na oprawach książek w formie rozłożonego wachlarza. Jest częstym motywem na oprawach ok. 1620 roku we Włoszech, Francji, Niemczech, Szwecji, Austrii. Encyklopedia wiedzy o książce, red. A. Birkenmajer, Warszawa 1971, kol. 679-680.

${ }^{104}$ Gieżyński, Wachlarz - kobiece berło.

${ }^{105}$ W 1711 roku angielski pisarz Joseph Addison w czasopiśmie „The Spectator” opublikował satyrę o Akademii Wachlarza, w której otwarcie mówił, że kobieta bez wachlarza jest jak mężczyzna bez szpady. Na salonach wszędzie było słychać ,,szept wachlarzy, szum wachlarzy i kłótnie wachlarzy". Często było to na tyle skomplikowane, że dobrze urodzonym pannom proponowano pomoc w opanowaniu tej trudnej sztuki. Kosieliński, Spojrzenie zza wachlarza, s. 46.

${ }^{106}$ Śliwa, Historia opowiedziana szeptem wachlarzy.

${ }^{107}$ Kosieliński, Spojrzenie zza wachlarza, s. 46. 
w Andaluzji, na przełomie XVIII i XIX wieku, w pałacach i na dworach damy używały ,języka wachlarzy”. Polegał on na odpowiednim ułożeniu wachlarza w czterech kierunkach, w pięciu różnych wariantach. Każdemu ruchowi abanico przypisany były jeden znak alfabetu ${ }^{108}$.

Z Europy Zachodniej wachlarze trafiły na ziemie północne, od Skandynawii aż po dwory hospodarów wołoskich. W Rosji doszło do swoistej syntezy tradycji: zanim jeszcze trafiły tam wachlarze francuskie, na Kremlu znano już potężne, poruszane przez sługi lub niewolników horyzontalne wachlarze, tzw. opachała ${ }^{109}$, które przywędrowały z Persji. Były to duże wachlarze z czarnych strusich piór, często ozdabiane perłami, szmaragdami i rubinami, umocowane na złoconym stelażu z lapis lazuli ${ }^{110}$. Mimo że składane pergaminowe wachlarze z Zachodu przy takim przepychu wydawały się bardzo niepozorne, carscy skarbnicy cenili je wysoko za finezję wykonania. W wieku XIX wachlarz rozpowszechnił się $\mathrm{w}$ życiu rosyjskich sfer wyższych $\mathrm{z}$ wielkim upodobaniem. Zapotrzebowanie na wyroby z kości zaspokajali rzemieślnicy z Archangielska i Lapończycy, a duma z nowoczesnych zakładów metalurgicznych $w$ Tule sprawiła, że przez długi czas wielkim uznaniem cieszyły się wyrabiane tam miniaturowe wachlarze z żeliwa lub stali ${ }^{111}$.

Epoka wachlarzy skończyła się wraz z I wojną światową. Zmieniło się społeczeństwo, weszły nowe technologie, przez co i moda, szczególnie kobieca, uległa zmianie. Sztywna etykieta wyższych sfer rozluźniła się, a wachlarze stały się pospolitym i zupełnie nieistotnym przedmiotem. W drugiej połowie XX wieku zainteresowanie tymi przedmiotami zupełnie zmalało. Może w XXI wieku, z powodu zmian klimatycznych, osobiste wachlarze (nie wymagające zasilania $\mathrm{z}$ zewnątrz) powrócą do łask, może także przybiorą nowe formy z wykorzystaniem nowoczesnych materiałów.

\section{BIBLIOGRAFIA}

Davidson Gustav, Stownik aniołów, w tym aniotów upadtych, Poznań 1998.

Dizionario di erudizione storico-ecclesiastica, comp. G. Moroni, vol. XXV, Venezia 1844 Enciclopedia Cattolica, Vaticano 1950

Encyklopedia wiedzy o ksiażce, red. A. Birkenmajer, Warszawa 1971.

Frédéric Louis, Życie codzienne w Japonii w epoce samurajów (1185-1603), Warszawa 1971. Leksykon liturgii, oprac. B. Nadolski, Poznań 2006.

Mol Serge, Broń dawnej Japonii, Bydgoszcz 2004.

${ }^{108} \mathrm{~W}$ hiszpańskim wydaniu ruch abanico (wachlarza) przerodził się w skomplikowany język, pełen namiętności i aluzji, w którym kochankowie mogli wyrażać gniew, obietnice i tęsknoty. Śliwa, Historia opowiedziana szeptem wachlarzy.

${ }^{109}$ Taki wachlarz został podarowany matce Piotra I, carycy Natalii, przez patriarchę konstantynopolitańskiego Cyryla. Siemionowa, Wachlarz który mówi.

${ }^{110}$ Lapis lazuli, lazuryt - kamień lazurytowy, nieprzejrzysty, o pięknej barwie lazurowo niebieski czasem o odcieniach niebieskich i fioletowych, ciemnoniebieskich, błękitnych. Słownik terminologiczny sztuk pięknych, s. 228.

${ }^{111}$ Siemionowa, Wachlarz który mówi. 
Możdżyńska-Nawotka Małgorzata, O modach i strojach, Wrocław 2002.

Najlepsza sekretu zasłona. Wachlarze w zbiorach Muzeum Teatralnego, oprac. K. Wodarska-Ogidel, Warszawa 2010.

Nowowiejski Antoni, Wykład liturgji Kościoła Katolickiego, t. 2, cz. 1, Warszawa 1902.

Orlandis José, Kościót katolicki w drugiej połowie XX wieku, Radom 2007.

Palazzini Pietro, Flabelli, w: Enciclopedia Cattolica, Vaticano 1950, kol. 1438-39.

\section{Różne typy wachlarzy}

Schlansky Kristina, Wachlarz w kulturze europejskiej, w: Chłodny powiew wachlarzy: wachlarz europejski od XVIII do XX w., Pszczyna 2015.

Stownik terminologiczny sztuk pięknych, red. K. Kubalska-Sulkiewicz, Warszawa 2019.

Stefański Jerzy, Flabellum, w: Encyklopedia katolicka, t. 5, red. F. Gryglewicz, Lublin 1989, kol. 312-13.

Szyller Ewa, Historia ubiorów, Warszawa 1967.

Żygulski Zdzisław jun., Kostiumologia, Kraków 1972.

Żygulski Zdzisław, Broń wschodnia: Turcja, Presja, Indie, Japonia, Warszawa 1986.

\section{Netografia}

Buchaechum, https://en.wikipedia.org/wiki/Buchaechum (dostęp: 21.05.2019).

Buchaechum-Korea. The fan dance, https://danceask.com/buchaechum-korea/ (dostęp: 21.05.2019).

Chinese fans, www.fancircleinternational.org/history/chinese-fans/ (dostęp: 11.05.2019).

Dunn Jimmy, Fans and Sunshades in Ancient Egypt, www.touregypt.net/featurestories/ fans.htm.

Fans, www.comuseum.com/culture/fans/ (dostęp: 11.05.2019).

Fans of Tutankhamun's tomb, www.fancircleinternational.org/history/fans-of-tutankhamunstomb/ (dostęp.08-09.05.2019).

Gieżyński Stanisław, Wachlarz - kobiece berło, https://www.weranda.pl/sztuak-new/ kolekcje-new/wachlarz-kobiece-berlo, (dostęp: 27.05.2019).

Gutkowska Marja, Historia ubiorów, Lwów 1932.

Japanese fans, www.fancircleinternational.org/history/japanese-fans/ (dostęp: 09.05 i 11.05.2019).

Joseon, https://pl.wikipedia.org/wiki/Joseon (dostęp: 21.05.2019).

Karnawat i jego rekwizyt, Muzeum w Kozłówce, http://muzeumzamoyskich.historia.org. $\mathrm{pl} / 2015 / 01 / 29 /$ karnawal-i-jego-rekwizyt/.

Koreanfightingfan,https://en.wikipedia.org/wiki/Korean_fighting_fan(dostęp:21.09.2019).

Kosieliński Sławomir, Spojrzenie zza wachlarza, w: „Wiedza i Życie” 1997 nr 1, s. 44-47.

Kotliński Mikołaj, Wachlarz jako atrybut - wachlarz jako broń, https://japonia-online.pl/ article/443.

Norenberg Marta, Historia wachlarzy cz. 1 - cieply powiew znad Śródziemnomorza, http://sztukkilka.pl/2017/05/14/historia-wachlarzy-cz-1/.

Punkah, https://en.wikipedia.org/wiki/Punkah (dostęp: 11.05.2019).

Punkah wallah, https://en.wikipedia.org/wiki/Punkah_wallah (dostęp: 11.05.2019).

Ripidion, https://fr.wikipedia.org/wiki/Ripidion (dostęp: 10.05.2019).

Sasaeng fan, https://en.wikipedia.org/wiki/Sasaeng_fan.

Selwa Matylda, Porozmawiajmy: o wachlarzach, cz.1, https://kolekcjonersurowcow. wordpress.com/2011/11/16/porozmawiajmy-o-wachlarzach-cz-1/. 
Selwa Matylda, Porozmawiajmy: o wachlarzach, cz. 2, https://kolekcjonersurowcow. wordpress.com/2011/12/20/porozmawiajmy-o-wachlarzach-cz-2/.

Siemionowa Jelena, Wachlarz który mówi, https://wiadomosci.onet.pl/kiosk/wachlarzktory-mowi/30cg3 (dostęp: 01.06.2019).

Śliwa Kinga, Historia opowiedziana szeptem wachlarzy..., http://muzea.malopolska.pl/ czy-wiesz-ze/-/a/10191/historia-opowiedziana-szeptem-wachlarzy\%E2\%80\%A6

Tak powstaje washi - tradycyjny, ręcznie robiony papier japoński, http://dziwowisko.pl/ washi-papier-japonski/ (dostęp: 15.05.2019).

Tyldesley Joyce, 8 things you (probably) didn't know about Tutankhamun, www. historyextra.com/period/ancient-egypt/8-things-you-probably-didnt-know-abouttutankhamun/.

Types of japanese fans, https:/www.theclassroom.com/types-of-japanese-fans-12080883. html (dostęp: 11.05.2019)

Wachlarze i ich mowa, https://wiadomosci.onet.pl/wachlarze-i-ich-mowa/gvf4n.

Wachlarz liturgiczny we wschodnim chrześcijaństwie, https://en.wikipedia.org/wiki/ Liturgical_fan_in_Eastern_Christianity (dostęp: 15.05.2019).

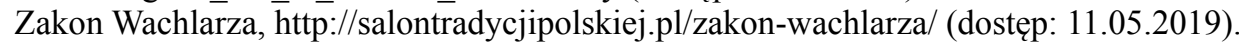

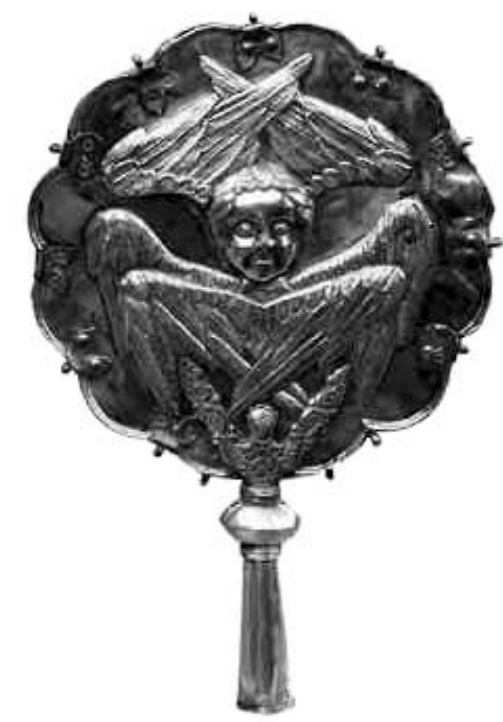

Il.1. Ripidion (Hexapteryga) z sześcioskrzydłymi serafinami (srebrny) 


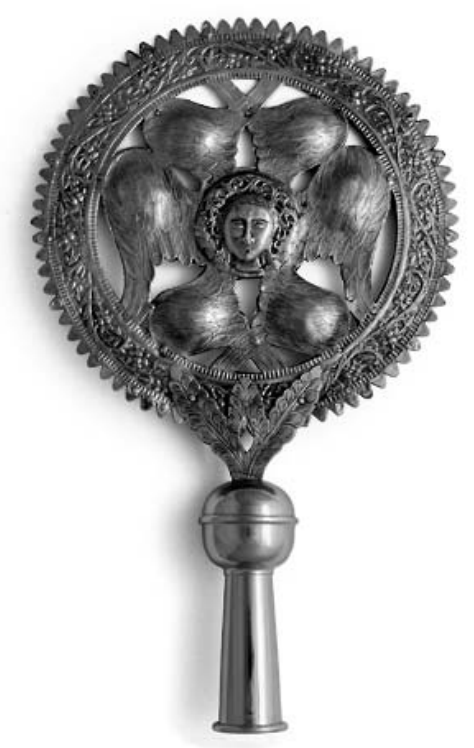

I1.2. Ripidion (Hexapteryga) z sześcioskrzydłymi serafinami (pozłacany)

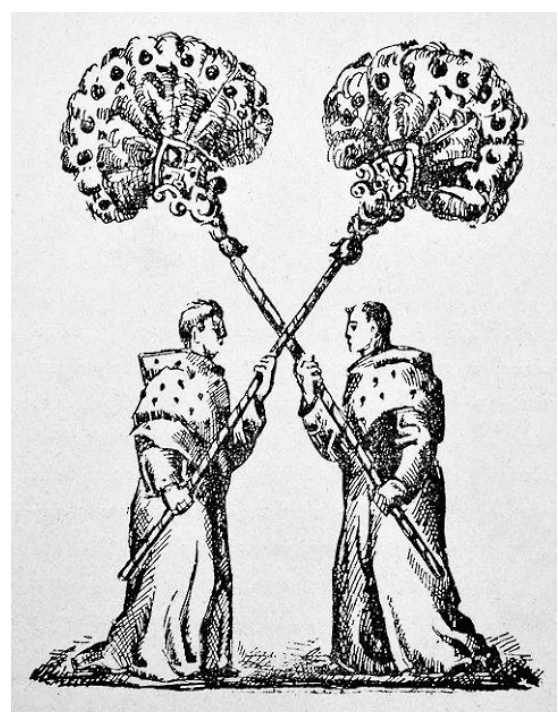

I1.3. Flabella ceremonialne ze strusich piór 


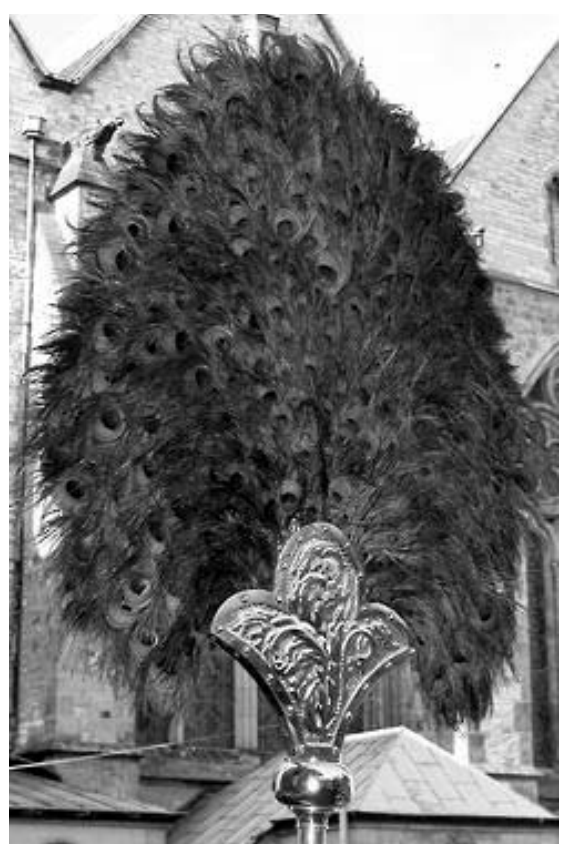

Il.4. Flabellum ceremonialne z pawich piór

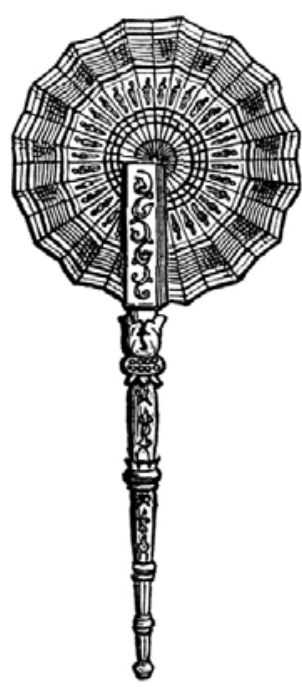

I1.5. Flanellum małe używane w liturgii 


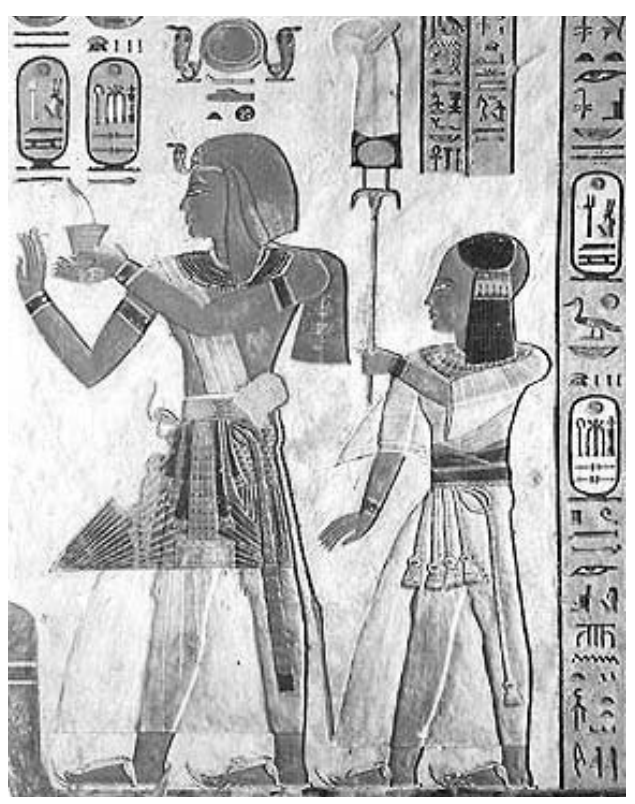

I1.6. Relief z grobowca Khaemwaseta - syna Ramzesa III w Dolinie Królowych (XII w. p.n.e.)

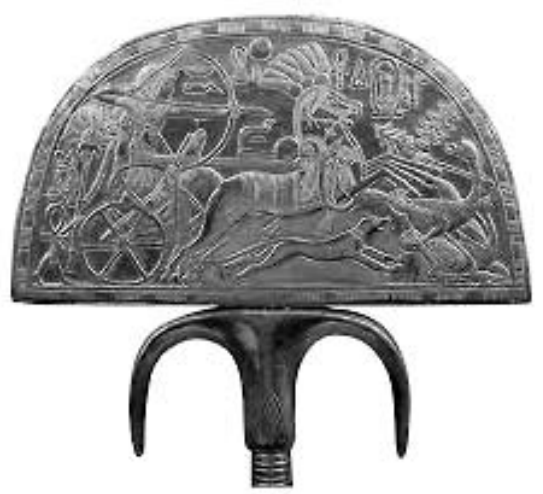

Il.7. Stelaż wachlarza Tutnchamona (XIV w. p.n.e.) 


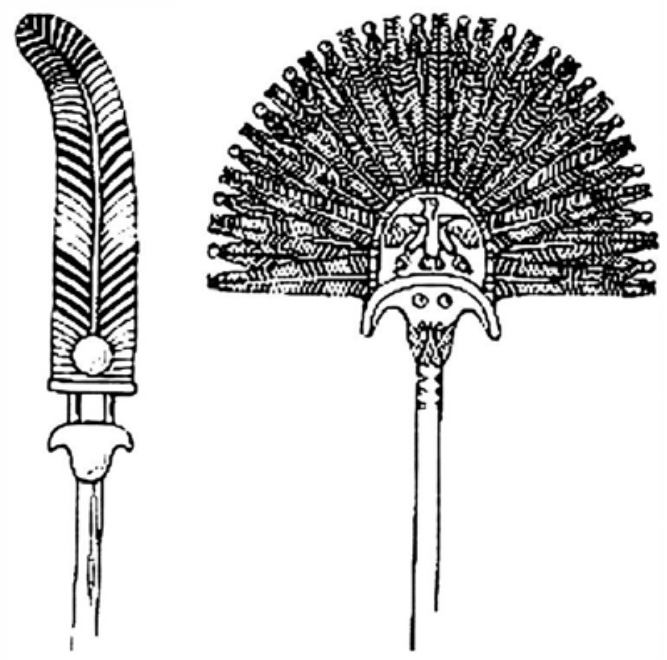

Il.8. Wachlarze egipskie

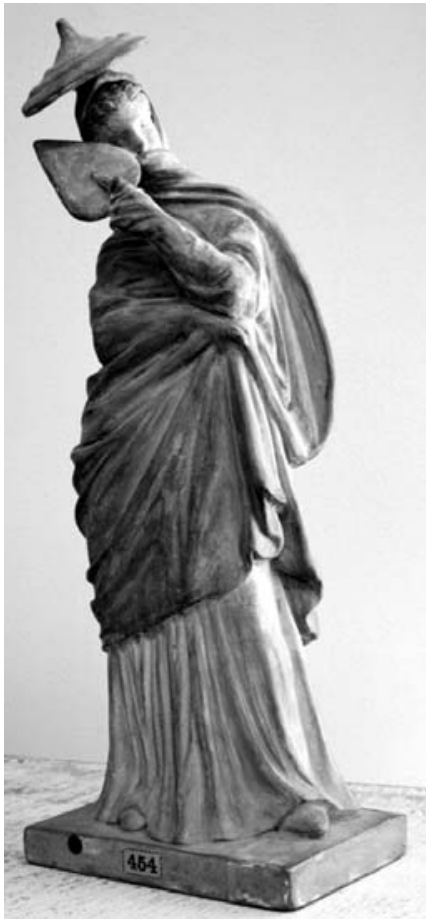

I1.9. Terakotowa figurka $\mathrm{z}$ Tanagry $\mathrm{z}$ wachlarzem (IV w. p.n.e.) 


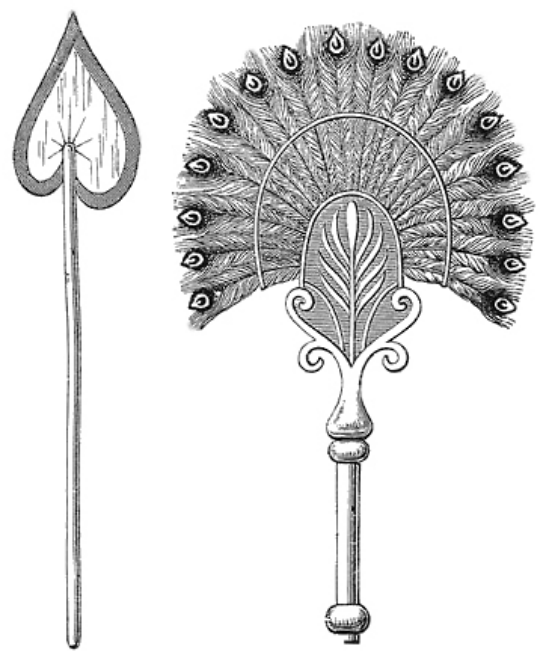

Il.10. Wachlarze etruskie

(Etruria - kraina historyczna w starożytnej Italii)

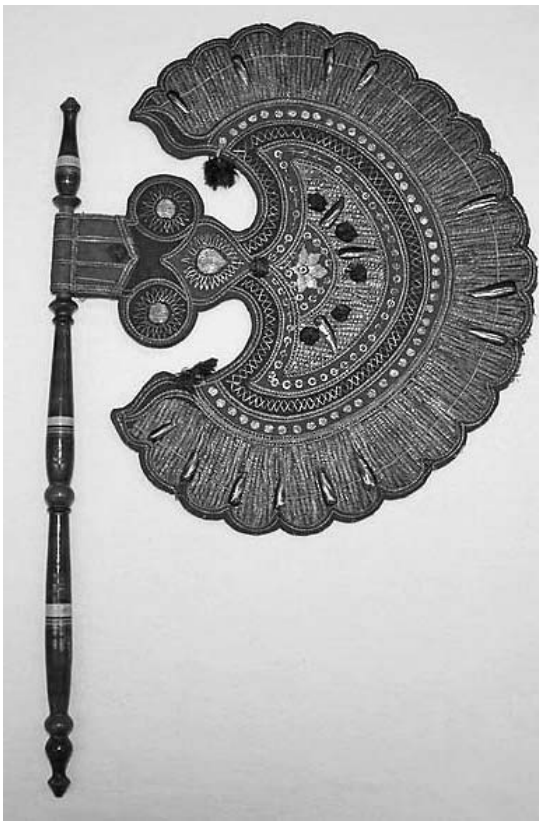

Il.11. Indyjski wachlarz typu chorągiewka 


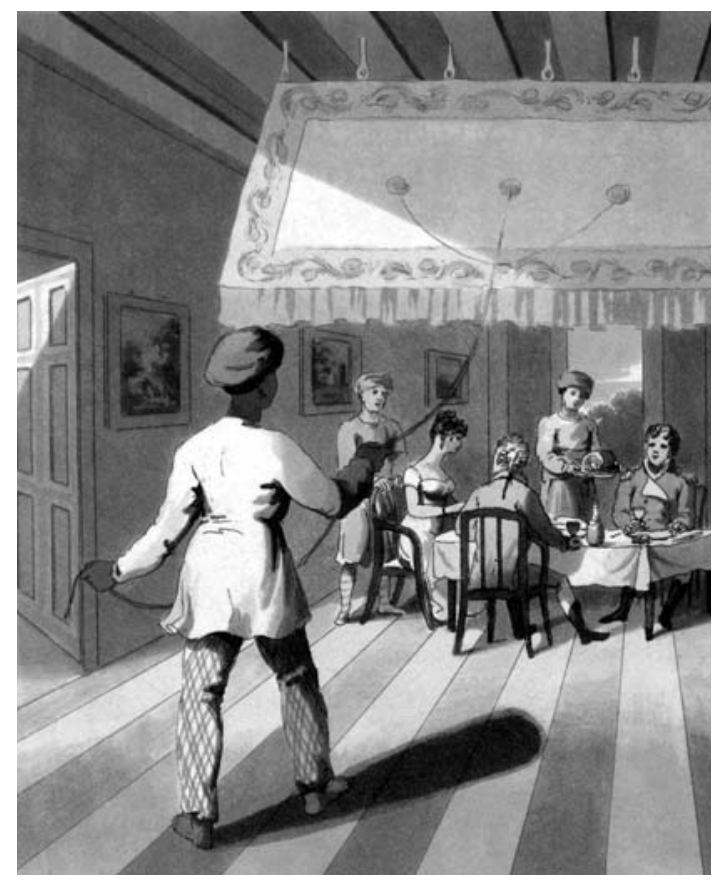

Il.12. Indyjski wachlarz punkah

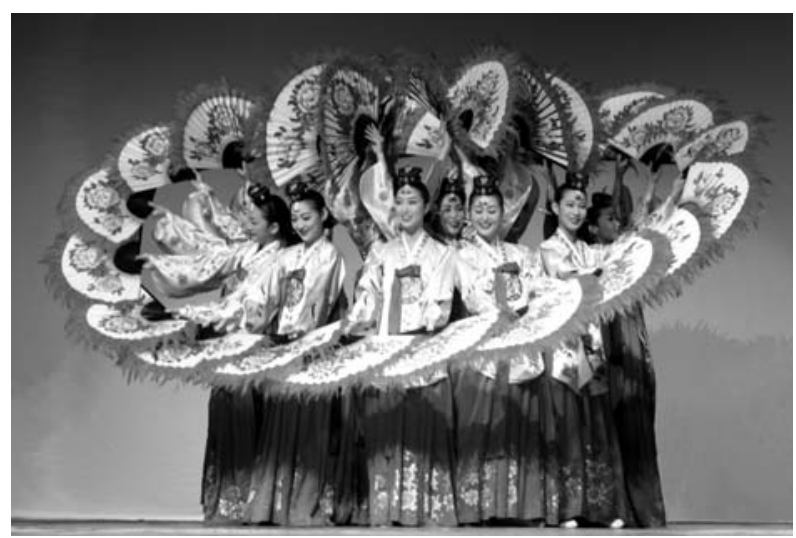

Il.13. Koreańskie wachlarze do tańca Buchaechum 


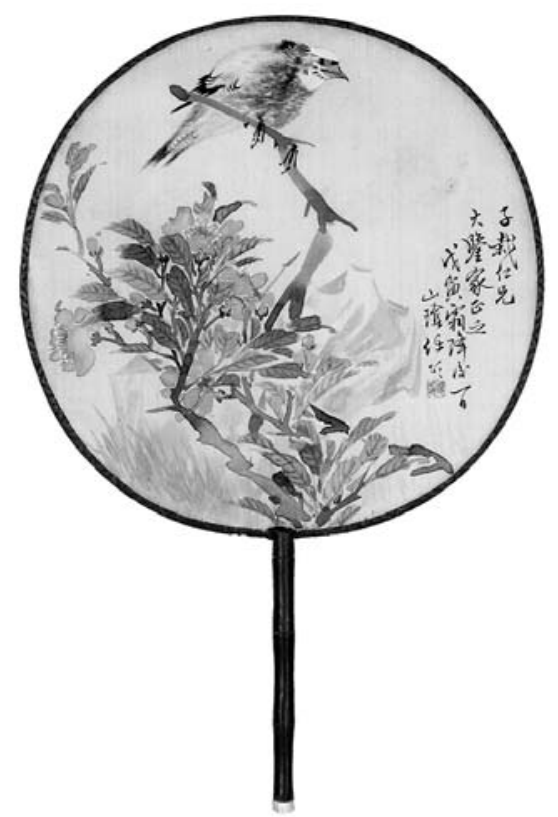

Il.14. Chiński wachlarz typu ekran

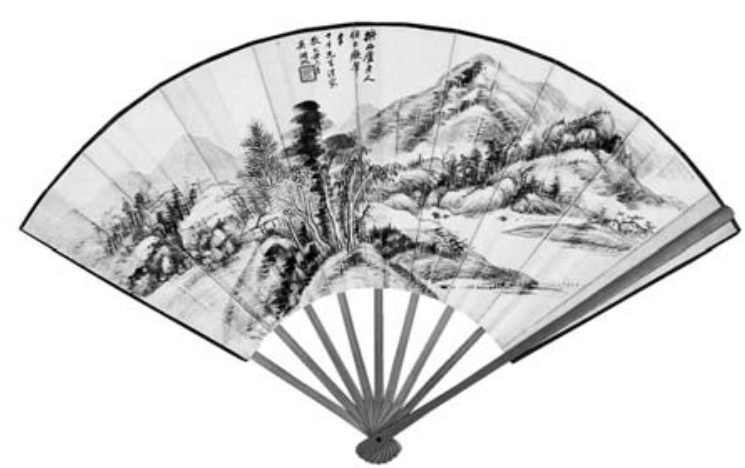

Il.15. Chiński wachlarz składany 


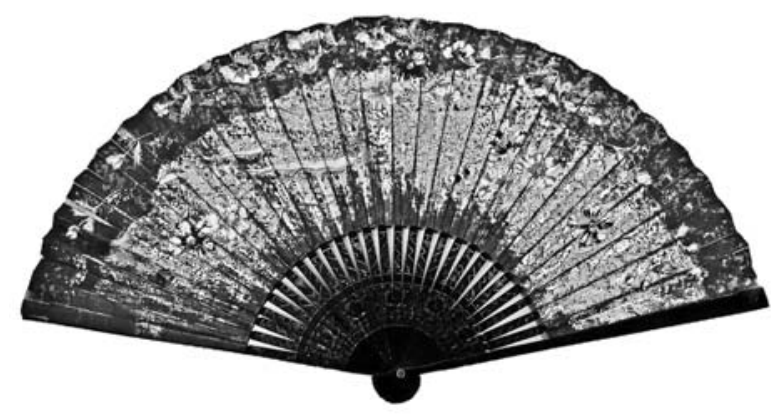

Il.16. Chiński wachlarz składany zhe shan

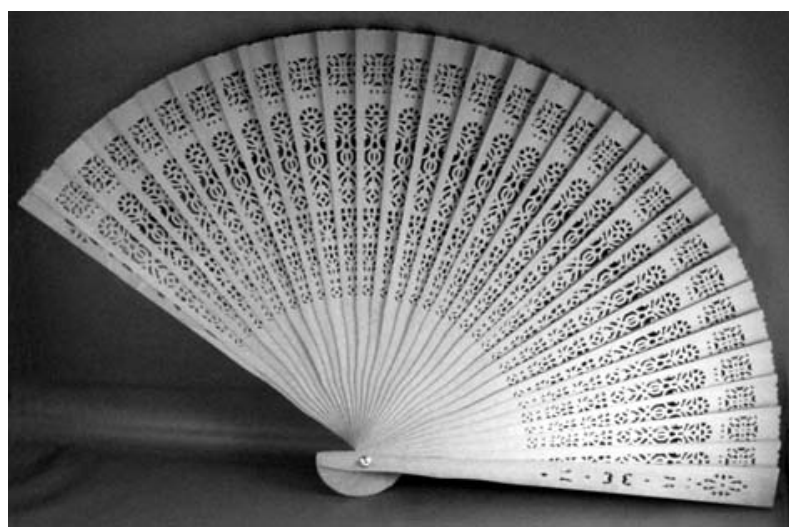

Il.17. Chiński wachlarz składany drewniany typu brisé 


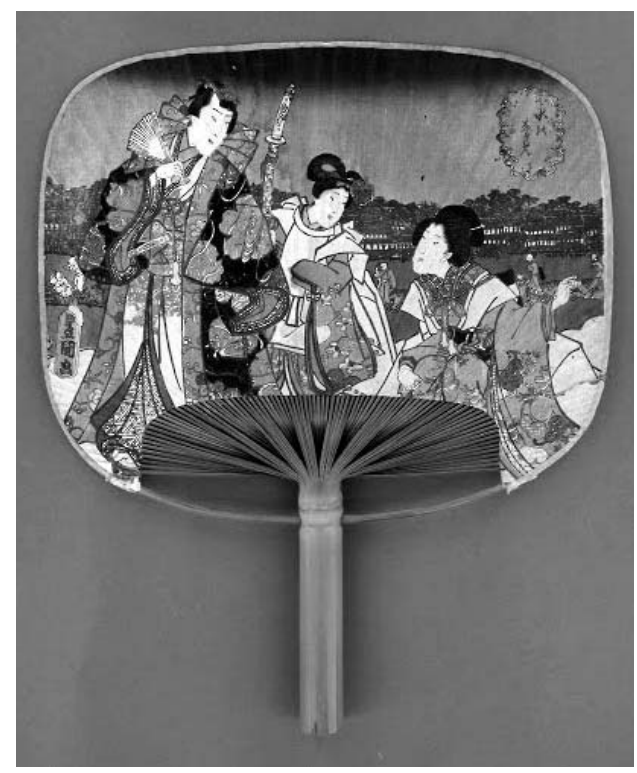

Il.18. Japoński wachlarz osobisty nieskładany uchiwa, dansen

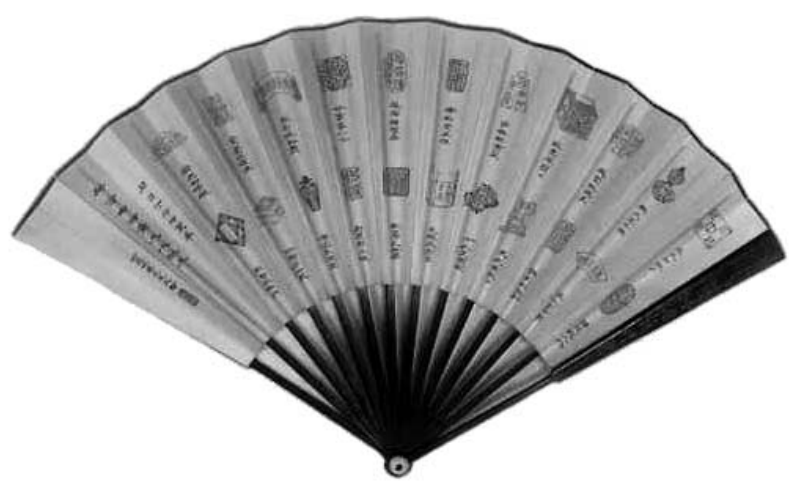

Il.19. Japoński wachlarz osobisty składany sensu, õgi 


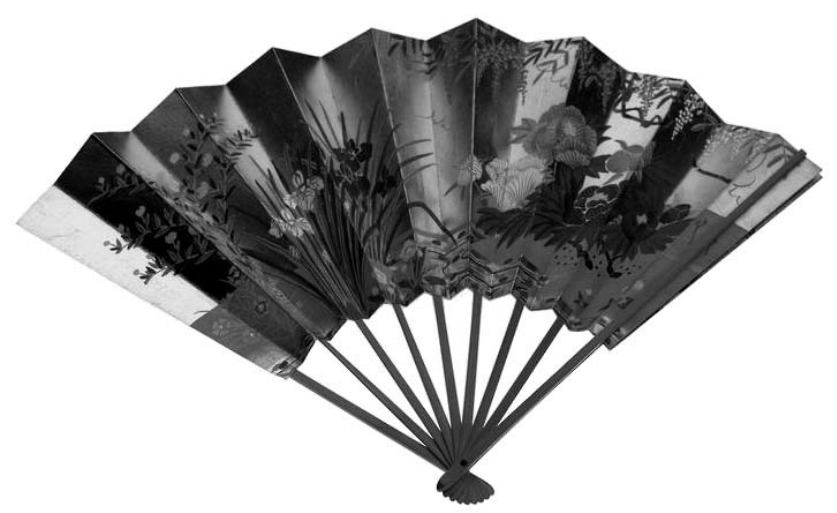

I1.20. Japoński wachlarz teatralny chukei, noh

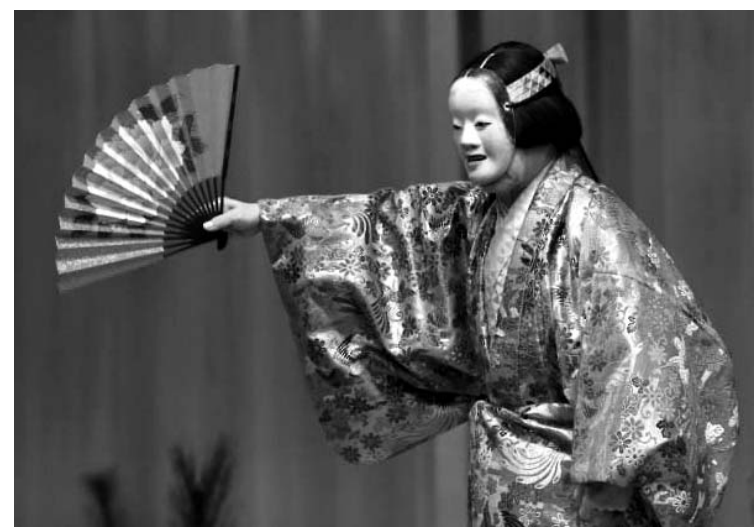

Il.21. Przedstawienie teatralne z użyciem wachlarza chukei 


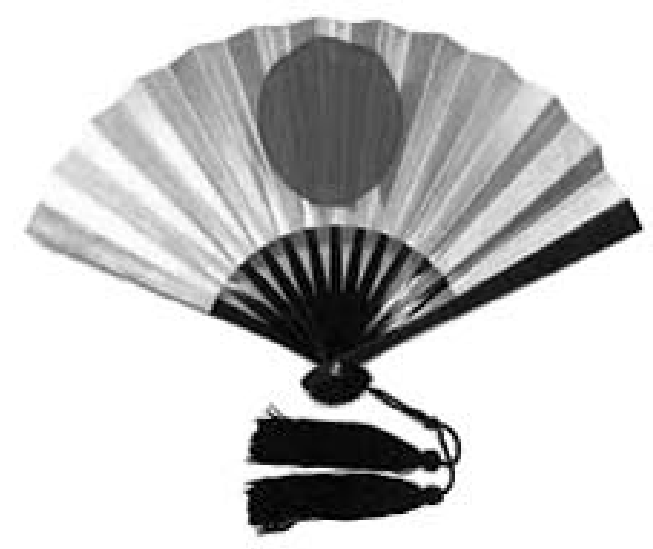

I1.22. Japoński wachlarz bojowy tessen

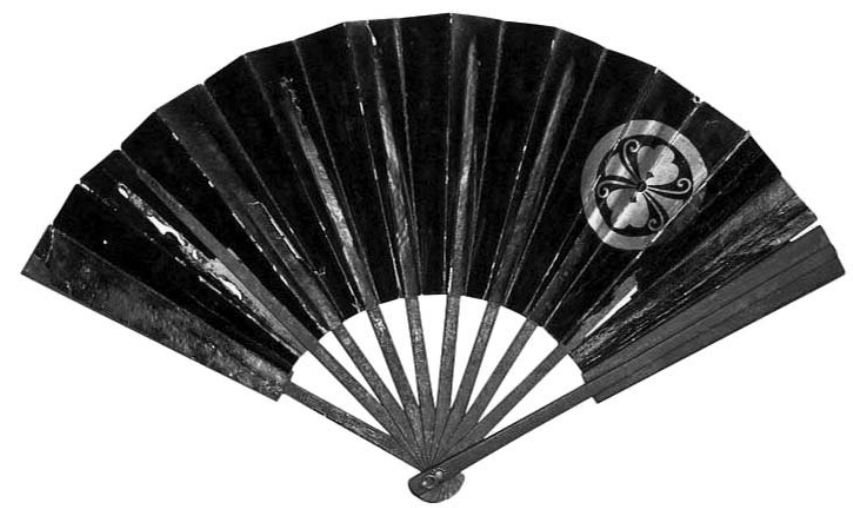

I1.23. Japoński wachlarz bojowy menbarigata tessen 


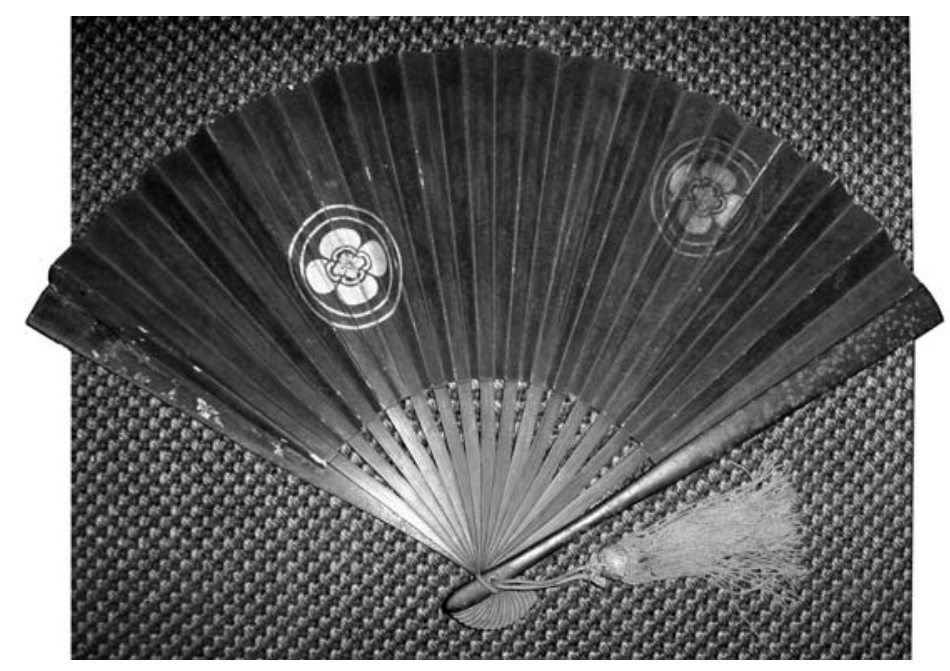

I1.24. Japoński wachlarz bojowy gunsen

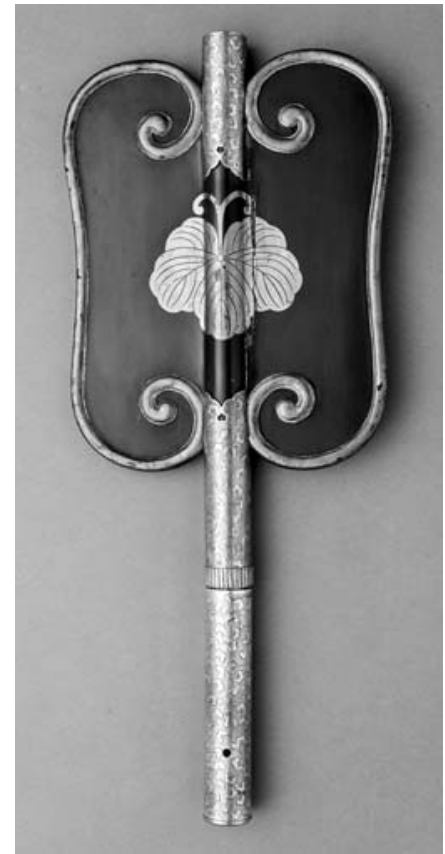

I1.25. Japoński wachlarz bojowy gunbai 


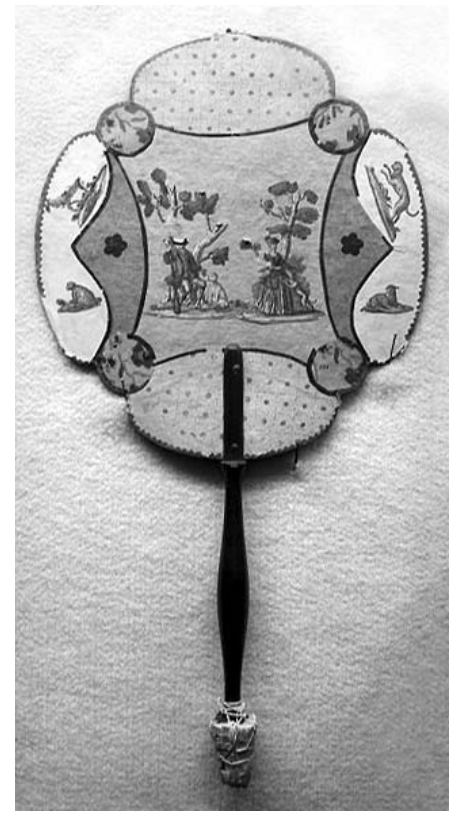

I1.26. Włoski wachlarz typu ekran (XVII w.)

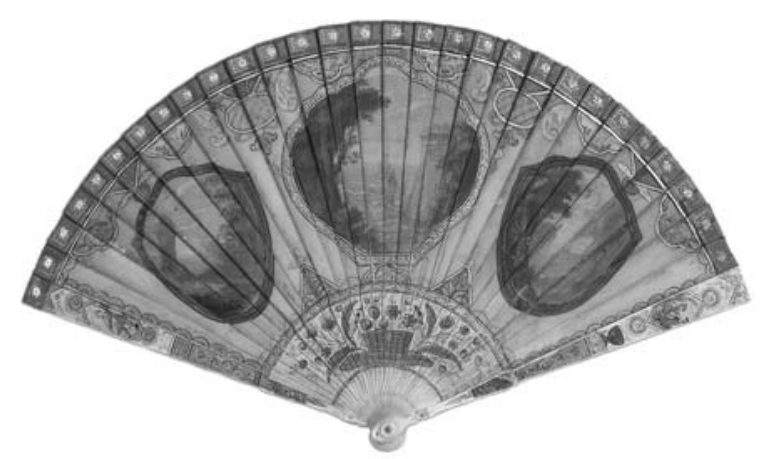

I1.27. Francuski wachlarz składany typu brisé (XVIII w.) 


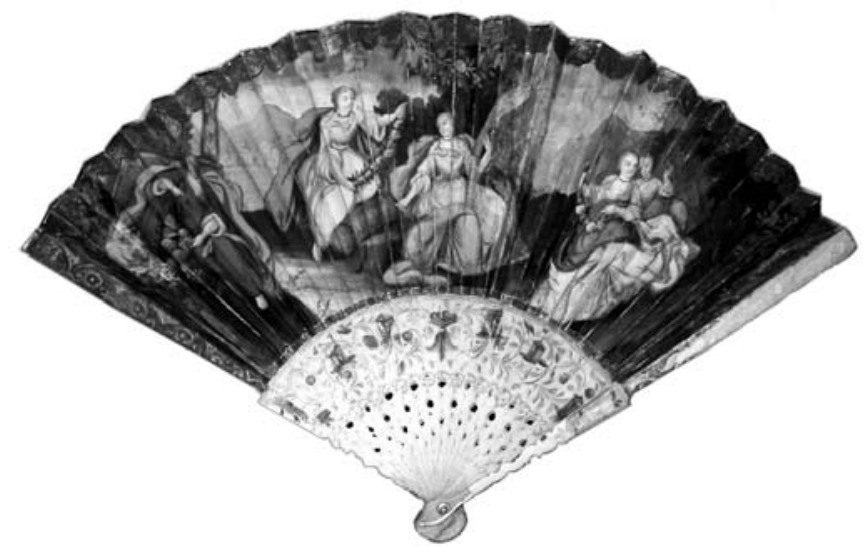

I1.28. Francuski wachlarz składany ze scenka rodzajową (XVIII w.)

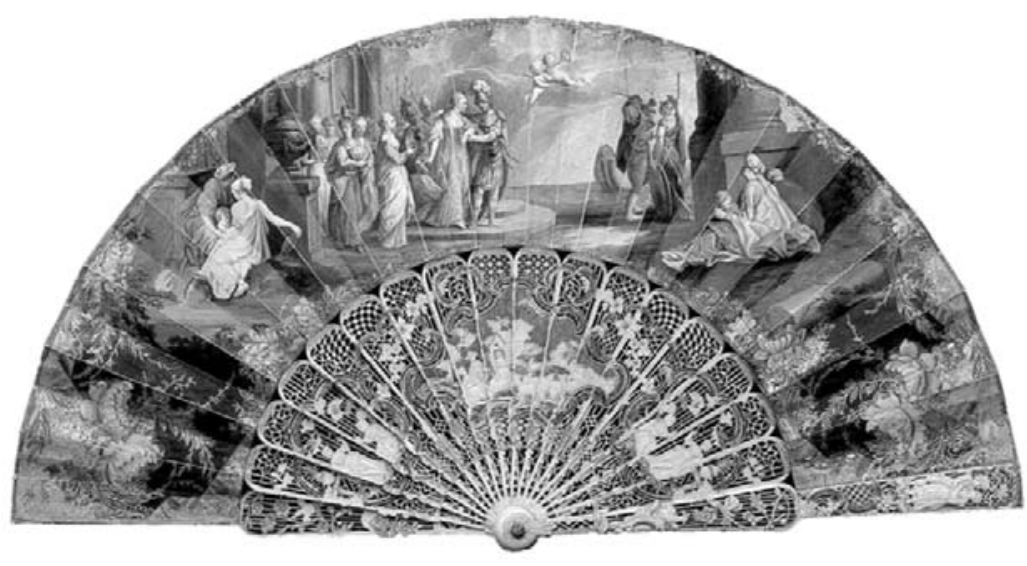

I1.29. Angielski wachlarz składany ze sceną alegoryczną (XVIII w.) 


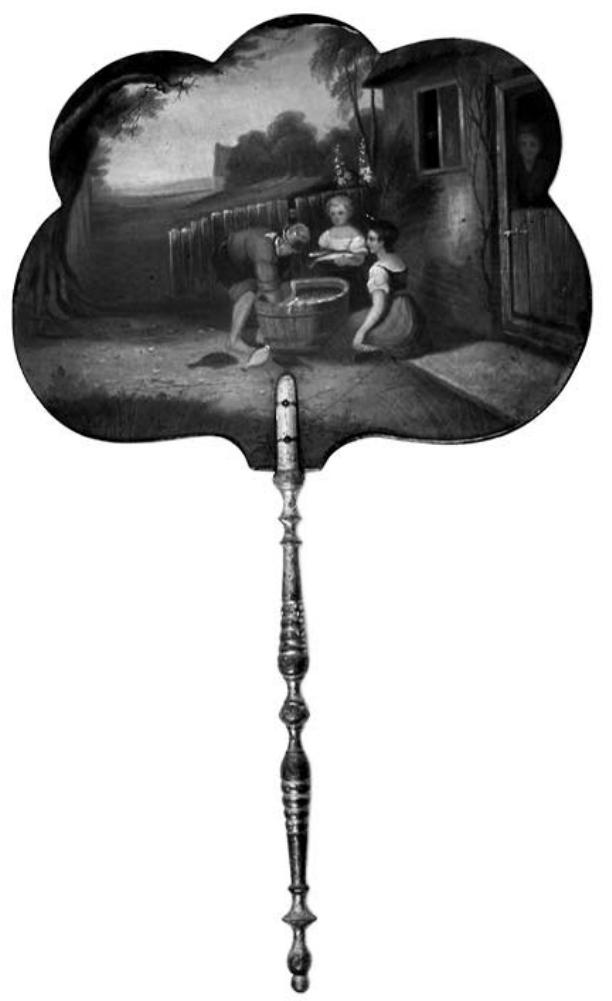

I1.30. Angielski wachlarz typu ekran (XIX w.) 


\title{
FAN IN THE EASTERN AND WESTERN CHURCH AND IN THE CULTURE OF THE WORLD
}

\begin{abstract}
Summary
The history of a fan - an object that could be seen as exquisite (or even superfluous) - is extremely rich and interesting from the point of view of customs, history and art history. It is amazing how this small object of everyday use, currently considered to be women's fashion utensils, has had multiple and important functions for millennia.

Since the earliest times, fans have been used for cooling, stripping insects, sun protection or setting fire. In ancient Egypt the fans were used by pharaohs and priests as attributes of power and grandeur. Until the 1950s, two fans (flabella) were used in the Western Church as an honorary distinction in processions during which the Pope was carried on shoulders on the gestatorial chair (sedia gestatoria). In the liturgy of the Eastern Church the use of fans (ripidia) has survived to our times, although their significance has already become entirely symbolic.

Battle fans come from the Far East, where they served primarily as a sign of officer rank, but also as a weapon. They were used from the 6th to the 16th century, when they reached the peak of popularity.

The fans arrived in Europe along with expeditions to the Far East. The golden times of fans came in the 17th and 18th centuries. They ruled in upper-class salons and royal courts throughout Europe. They have become a symbol of prosperity, refinement and coquetry regardless of the time of year. The fan has become the attribute of a lady. Folding fans have gained the most popularity.

The fans were made of wood, precious metals, ivory, tortoiseshell, leather, parchment, silk, linen, paper, feathers, and also leaves. They were carved, painted, embroidered and decorated with jewels. They took different forms depending on the application and needs. They were small and large, straight, folded, pleated, round, semicircular, in the shape of a leaf or a streamer, on a long or short handle.
\end{abstract}

Key words: fixed fan; folding fan; brisé; ripidion, flabellum; Japanese personal; theater and military fans; Chinese fan; Korean fan 